Review

\title{
Lipids from Hermetia illucens, an Innovative and Sustainable Source
}

\author{
Antonio Franco ${ }^{1,2, \dagger}$, Carmen Scieuzo ${ }^{1,2,+}$, Rosanna Salvia ${ }^{1,2, *,+} \mathbb{D}^{\mathbb{D}}$, Anna Maria Petrone ${ }^{1}$, Elena Tafi ${ }^{1}$, \\ Antonio Moretta ${ }^{1}$ (D) Eric Schmitt ${ }^{3}$ (D) and Patrizia Falabella ${ }^{1,2, *(D)}$
}

1 Department of Sciences, University of Basilicata, Via dell'Ateneo Lucano 10, 85100 Potenza, Italy; antonio.franco@unibas.it (A.F.); carmen.scieuzo@unibas.it (C.S.); annamariapetrone1988@gmail.com (A.M.P.); elena.tafi@unibas.it (E.T.); antonio.moretta@unibas.it (A.M.)

2 Spinoff XFlies s.r.l, Department of Sciences, University of Basilicata, Via dell'Ateneo Lucano 10, 85100 Potenza, Italy

3 Protix B.V., Industriestaat 3, NC 5107 Dongen, The Netherlands; eric.schmitt@protix.eu

* Correspondence: r.salvia@unibas.it (R.S.); patrizia.falabella@unibas.it (P.F.)

+ These authors contributed equally to this work.

check for updates

Citation: Franco, A.; Scieuzo, C.;

Salvia, R.; Petrone, A.M.; Tafi, E.;

Moretta, A.; Schmitt, E.; Falabella, P. Lipids from Hermetia illucens, an Innovative and Sustainable Source. Sustainability 2021, 13, 10198. https://doi.org/10.3390/su131810198

Academic Editor: Attila Gere

Received: 16 July 2021

Accepted: 8 September 2021

Published: 13 September 2021

Publisher's Note: MDPI stays neutral with regard to jurisdictional claims in published maps and institutional affiliations.

Copyright: (C) 2021 by the authors Licensee MDPI, Basel, Switzerland. This article is an open access article distributed under the terms and conditions of the Creative Commons Attribution (CC BY) license (https:// creativecommons.org/licenses/by/ $4.0 /)$

\begin{abstract}
The exponential increase of global demand for proteins and lipids can no longer be satisfied by classical sources. High amounts of $\mathrm{CO}_{2}$ produced by intensive livestock breeding and its effects on the environment are the main factors that prevent the use of animals as primary sources for proteins and lipids, calling for the use of new sustainable sources, such as insects. The massive breeding of bioconverter insects as a feed source has been a major topic in recent years, with both economic and scientific aspects related to rearing and subsequent processing optimization. The larvae of Hermetia illucens (Diptera: Stratiomyidae) (also known as Black Soldier Fly) can be used for the eco-sustainable production of proteins and lipids with high biological and economic value. Lipids can be obtained from BSF bioconversion processes and are present in high quantities in the last instar larvae and prepupae. Fats obtained from BSF are used as animal feed ingredients, in the formulation of several products for personal care, and in biodiesel production. To enable the use of insect-derived lipids, it is important to understand how to optimize their extraction. Here, we summarize the published information on the composition, the extraction methods, and the possible applications of the BSF lipid component.
\end{abstract}

Keywords: bioconversion; fats; sustainability; animal feed; biodiesel; Black Soldier Fly

\section{Introduction}

Insects are the greatest example of biodiversity on earth and their role in the ecosystem is extremely varied [1]. Although insects are often considered pests, they provide important ecological services, above all pollination of wild flora and crops, and are a source of useful biomolecules [2]. Insects also act as reliable indicators of environmental quality [3], and they can be used as a tool for biological control of pests [4]. Moreover, insects could represent innovative and alternative models in biological, medical and environmental studies [5], and they are one of the best sources of inspiration for biomimicry, to develop useful innovations for improving the quality of life through the use of biotechnology. Indeed, insects can represent a new source of genes, molecules and mechanisms of interest to agriculture, forestry, biomedicine and industry, as well as in other technological applications [6].

Bioconverter species represent an important group of insects from an ecological point of view, as they are able to consume many animal and plant decaying organic substrates during their larval development, when they are growing rapidly and accumulating biomass. Thus, several food waste and by-products can potentially be recovered and used as feed for these insects, rather than having to be disposed of in a conventional way, acquiring a new value. 
In recent years, among bioconverter insects, particular attention has been given to Hermetia illucens (Diptera: Stratiomyidae) (also known as Black Soldier Fly-BSF). BSF larvae are able to feed on various organic substrates of vegetable and animal origin, even in decomposition, bioconverting them into larval biomass in just 14 days under optimal growth conditions $\left(27^{\circ} \mathrm{C}\right.$ of temperature and $70 \%$ of humidity) [7-9]. The wide variety of organic materials that BSF is able to feed on includes manure [10], waste from the agri-food chain [11,12], distilled grain waste such as spent malt [13-15], and many others [11]. These insects have a potentially great economic role from the perspective of a circular economy, as they are able to consume organic waste material and convert it into insect biomass that can in turn be used as feed for other livestock and food for humans [16,17].

In many countries, especially in tropical regions, insects represent an important component of the human diet. More than 2000 species are recognized as edible (e.g., bees, caterpillars, termites, cicadas, crickets, ants) and have high nutritional value [18]. Another important environmental reason for replanting meat with insects as an alternative protein source is the reduction in emissions of greenhouse gases, land use and pollution [18]. The ever-increasing world population and, consequently, the growing demand for food and agricultural land and over-production of food waste, combined with the depletion of natural resources and climate change, lead to a worldwide realization that new alternative sources of human food and animal feed are needed. In this scenario, insects appear to be a valid and sustainable source of nutrients and an innovative and marketable solution for waste management.

Considering that one third of global agricultural and food production is wasted [19] and that insects can be grown on former foodstuffs, they represent the key solution for reducing food waste, converting them into valuable products, including animal feed, human food, lubricants, pharmaceuticals and biofuel [20].

Insect Rearing

Insects have been identified by the United Nations Food and Agricultural Organization as a potential feed for animals [21-23], if fed on authorized substrates [24]. Recently, the EU authorized the use of insect proteins in feed for farmed fish [24]. This authorization regards only seven species of insect: BSF, the common housefly (Musca domestica), yellow mealworm (Tenebrio molitor), lesser mealworm (Alphitobius diaperinus), house cricket (Acheta domesticus), banded cricket (Gryllodes sigillatus), and field cricket (Gryllus assimilis) [25].

As a consequence, the breeding of these insect species for the production of feed has been increasing. Insect farming is more eco-sustainable, requiring fewer natural resources (in terms of soil, water, fertilization) than conventional crops such as soy that are widely used as feed for livestock and whose production competes with the production of food for human consumption [26-28]. Furthermore, insect breeding farms emit lower levels of greenhouse gases and ammonium $\left(\mathrm{NH}_{3}\right)$ compared to conventional livestock [29,30]. Finally, insects could be used to fight malnutrition in developing countries [31]. For insect farming there are also fewer animal welfare constraints than for other conventionally farmed animal species [27,32]. Insects present few risks regarding the transmission of infections and zoonoses [33], being taxonomically distant from common farmed species. However, insects are potential vectors of medically relevant pathogens and the risk of infections could rise with the improper use of waste products and with unhygienic handling of insects [27]. An obvious example is the common housefly, which can be a vector and reservoir for foodborne diseases and can be responsible for transmission of bacterial diseases. Moreover, housefly larvae, generally raised on substrates containing manure of different animal species [34], can pick up and transport different pathogens. This does not occur in BSF, since the adult stage does not have functioning mouthparts and, thus, they are not associated with transmissions of diseases, or to the accumulation of pesticides or mycotoxins [35-37]. Larval treatments at suitable temperatures during the drying process ensure the destruction of pathogenic organisms present in the larvae [38].

According to Regulation (EU) 2017/1017 [39], insects can be fed with waste produced by humans only for research purposes [40]. The great diversity of insect species, the 
different types of food on which they feed, and the different ecological niches determine an enormous variability in their composition [1,41,42]. Furthermore, bioconverter insects can transform abundant quantities of organic waste into a biomass rich in proteins and lipids that is suitable for animal nutrition [21,43,44] (Figure 1). Proteins, lipids, and chitin, the three main components of insects, can be properly isolated from these organisms to be used as food ingredients or for other applications in order to obtain high added value marketable products [45]. Many insects can be also used entirely in the form of powder rich in protein and/or lipid [46]. Recently EFSA approved the use of whole dried T. molitor larvae also for human consumption [47].

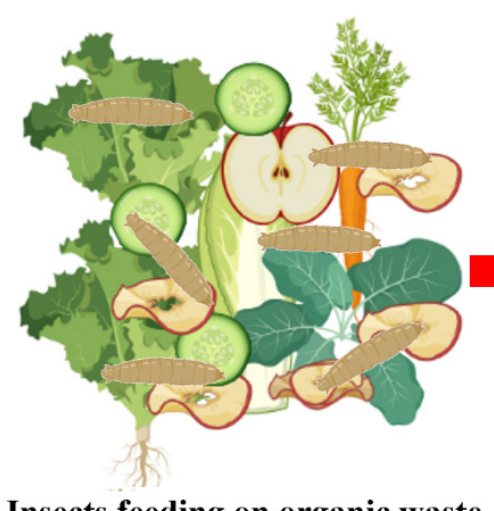

\section{Insects feeding on organic waste}

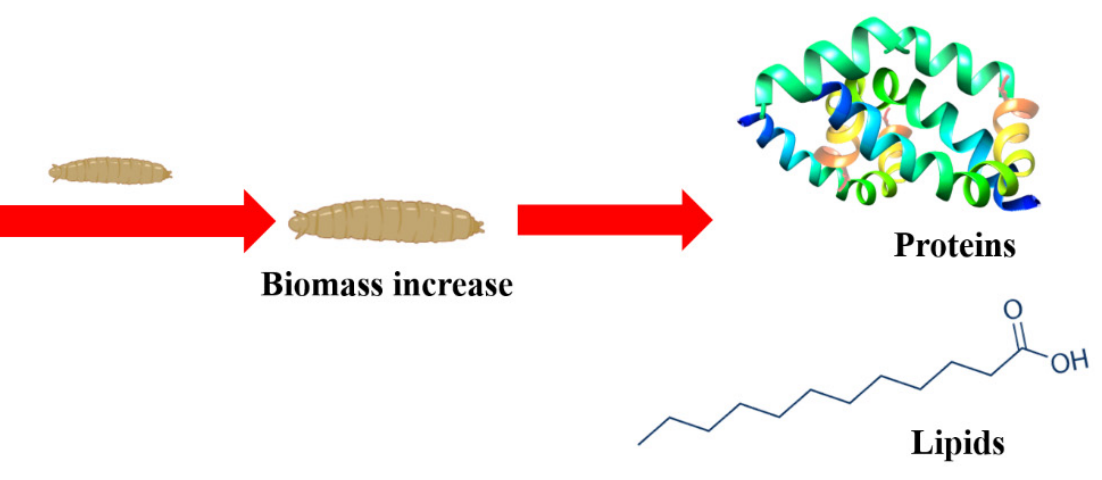

Figure 1. Insects can transform organic waste into animal biomass, which is rich in proteins and lipids.

Among the bioconverter species, BSF is considered one of the most interesting insects worldwide for the bioconversion of organic waste and as a promising and sustainable source of proteins, lipids, and bioactive compounds (i.e., chitin and antimicrobial peptides) [43,48-51] (Figure 2).

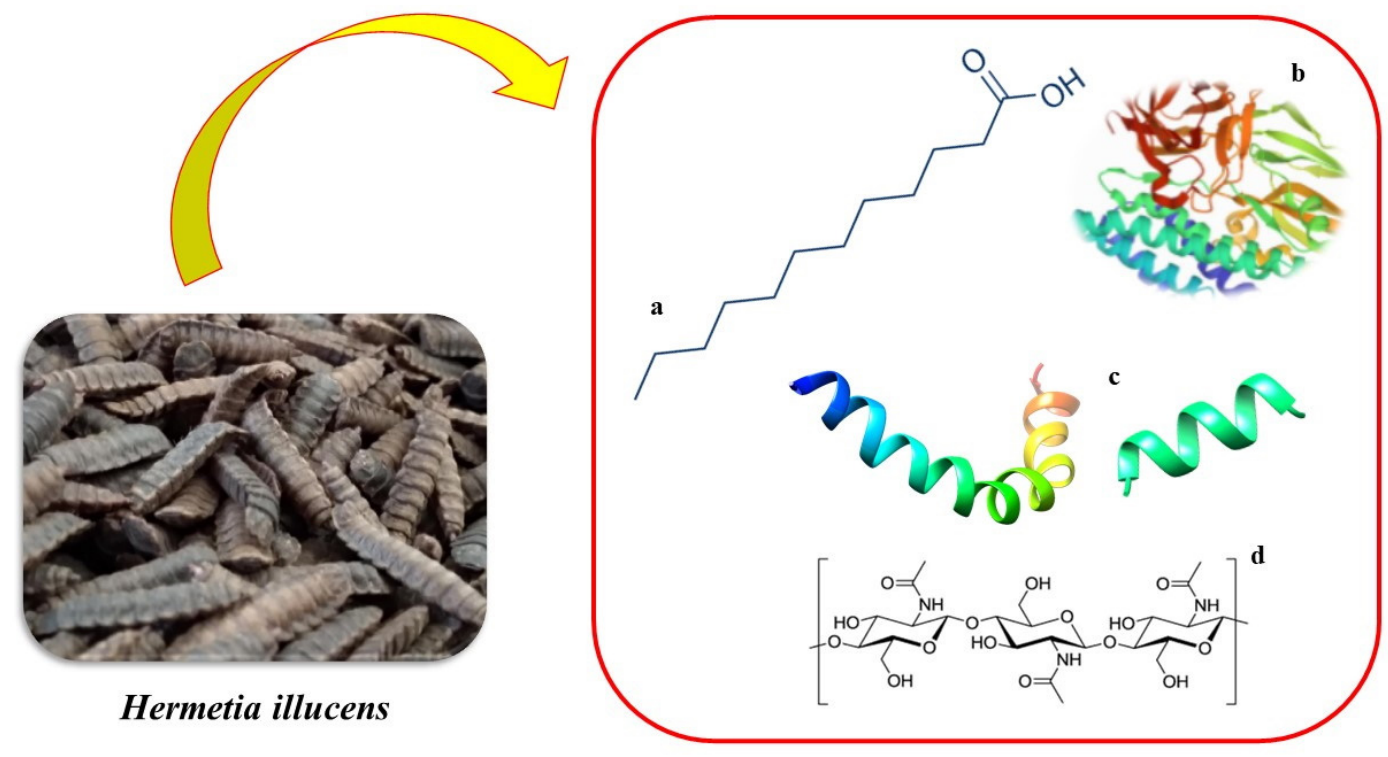

Figure 2. BSF is a sustainable source of lipids (a), proteins (b), antimicrobial peptides (c) and chitin (d).

The importance of BSF is correlated to its ability to convert and recover nutrients from different types of organic compounds and to reduce organic waste biomass by $50-60 \%$, thereby transforming it into high protein biomass [17].

This review is focused on the lipid fraction extractable from BSF, with the aim of investigating its composition, the lipid extraction methods currently available, and the possible applications of BSF lipids. 


\section{Lipids from the Black Soldier Fly}

BSF larvae (BSFL) are particularly rich in lipids, ranging from $15-49 \%$ of their weight. The composition of this fat, with more saturated than unsaturated fatty acids, is influenced by the type of growing substrates [52].

Fasakin et al. [53] reported that BSFL and the resulting whole meal have a fat content that exceeds the diet requirements of most animals to which they are fed [53]. This high fat content, together with other intrinsic factors of the lipids themselves, may influence the digestibility and/or the palatability of the meal. This lipid surplus of BSFL can be isolated and used for other purposes, e.g., food ingredients [54,55].

Lauric acid is among the most abundant fatty acids in BSFL, reaching a content up to $50 \%$ of the isolated fats $[21,43,45,56]$. However, the fatty acid composition of BSFL lipids can be modified according to the different feeding substrates [21,43].

\subsection{Larval Biomass Lipid Content Based on Different Diet}

Lipid content in both BSF last instar larvae and prepupae can reach $15-49 \%$ of the total dry weight, depending on the food substrate administered to the larvae [43,49]. As reported by Barragan-Fonseca et al. [57], feeding substrates can affect the larval body composition in terms of both protein and fat content. For instance, larvae have higher protein and lipid content when grown on swine manure instead of cow manure [58]. Substrates affect mainly the macronutrient levels (proteins, lipids, and carbohydrates) [58] and to a lesser extent the micronutrient concentrations (minerals and vitamins) $[21,58,59]$ that are very important for the needs of some wild animals in captivity [58].

Lipid content in BSFL is affected by the composition of the rearing substrate $[21,60,61]$ but the resultant crude fat content in BSFL is much higher than other insects, soybean, or fish meal $[62,63]$. Substrates with high amounts of proteins, lipids and, in general, substrates complete and balanced in all nutrients, are the best for the development of the BSF and its bioconversion performances [64]. Macronutrients in the substrate can affect the protein content of BSFL, larval weight, bioconversion rate, and development time [65-67].

The carbohydrate content of the feed substrate affects the lipid content of the BSFL $[65,67]$ because of the conversion of carbohydrate into lipids by larvae $[65,68]$. Low protein and high carbohydrate substrates allow a higher lipid accumulation in BSF larval biomass [69] than a balanced diet (a mix of ingredients with a final equilibrated ratio of proteins, lipids and carbohydrates) $[21,57,65,70]$. Moreover, the lipid composition can be directly affected by the lipid composition of the feeding substrate [65,71-73].

Makkar et al. [62] reported a lipid content ranging between 15-and 25\% for larvae fed on chicken manure, $28 \%$ on pig manure, $35 \%$ on cattle manure, and $42-49 \%$ on oil-rich food waste. Several studies utilized alternative substrates not suitable for human consumption (e.g., biogas digestate and many types of manure) to feed BSFL. The effect of the use of these substrates, particularly on the lipid content of BSFL, has been investigated by Spranghers et al. [21]. They demonstrated how lipid components in BSF prepupae vary as a function of substrates, rearing them on four different organic substrates: vegetable waste, chicken feed, restaurant waste, and biogas digestate. The lipid contents of these substrates were rather low $(2.1-6.2 \%)$ with the exception of restaurant waste $(13.9 \%)$. The authors found high fat content (mostly rich in short chain fatty acids) in larvae reared on energy rich substrates as restaurant waste (in which lipid component was around $38.6 \%$ ), vegetable waste (lipid component $=37.1 \%$ ), and chicken feed (lipid component $=33.6 \%$ ). A lower amount of lipids was found in larvae reared on digestate (21.8\%). These differences could be related to the higher uptake of fatty acids in larvae fed on high-energy substrates (rich on lipids and fatty acids). Restaurant waste was rich both in fat and non-fibre carbohydrates; vegetable waste and chicken feed were rich in non-fibre carbohydrates; while non-fibre carbohydrates were almost absent in the biogas, because of the fermentation process performed by microorganisms, transforming most of the carbohydrates in methane [21].

Concerning the different types of manure, the influence of this substrate on the lipid content of the BSFL feeding on it depends greatly on the origin of the manure. [36,74]. For 
example, a lipid content of $15-35 \%$ was found in larvae fed on poultry manure [36,74], $28-34 \%$ in larvae fed on swine manure [36,75], $14 \%$ with horse manure [76] and $10 \%$ with sheep manure [76].

Meneguz et al. [77] compared performances and composition of BSFL grown on fruit waste, on a mix of vegetables and fruit waste, and winery and brewery by-products.

Larvae reared on fruit waste showed higher fat content than larvae reared on vegetablefruit waste, probably as a consequence of the higher non-structural carbohydrate level of fruit waste (sugars, starch, pectins: energy and reserve substances contained in the plant cell) [78], which insects are able to convert into fats [21,79]. Nonetheless, the influence of the non-structural carbohydrates on the lipids content of BSFL should be further investigated, since the higher non-structural carbohydrate content in the brewery by-product did not lead to higher larval fat content [77].

Scala et al. [13] investigated on an industrial scale the influence of six different diets on BSF larval development, growth, final larval yield, substrate reduction, protein, and lipid content. The tested by-products were apple, banana, and spent grain, alone or mixed in 1:1 ratio $(w / w)$. This study detected the highest percentage of lipids in larvae fed with apple and mixed apple and banana. Larvae fed on spent grain, on a mix of apple and spent grain, and on a mix of banana and spent grain had the lowest percentage of lipids. Low percentage of lipid content in BSFL corresponds to a high percentage of proteins [13].

In Table S1 the lipid content of BSF biomass reared on different organic waste is reported.

\subsection{Fatty Acids Composition in Black Soldier Fly Lipids}

The lipid fraction of BSFL is a mix of triglycerides, saturated, and unsaturated fatty acids $[43,80]$. A study performed by Surendra et al. [81] on larvae fed on a mix of organic waste showed that the concentration of the short chain saturated fatty acids (lauric acidpalmitic acid) (67\% of total fatty acids) in the BSF prepupae fat was higher than coconut oil and palm kernel oil (55-57\% of total fatty acids), which is consistent with the results obtained by other authors $[45,62,80,82,83]$. Moreover, they found that the concentration of unsaturated fatty acids ( $28 \%$ of total fatty acids) was higher than in coconut oil $(10 \%)$ and higher than palm kernel oil (18\%) [78]. Meneguz et al. [77] affirmed that C18:1 (n-9) (oleic acid) was the main represented monounsaturated fatty acid in BSFL, while C18:2 (n-6) (linoleic acid) and C18:3 (n-3) (alpha-linolenic acid) were the main represented polyunsaturated n-6 and polyunsaturated n-3 fatty acids, respectively. Ushakova et al. [80] showed that azelaic and sebacic acids, the esters of lauric acid, are also present in the lipid fraction of BSF. The esters, including the identified azelaic acid dibutyl ether, could guarantee the elasticity of the fat component of larvae at low temperatures [80]. However, in BSF, azelaic acid is present in very low quantities $(0.83 \%)$, as reported in Ushakova et al. [80], and for this reason the melting point of other fatty acids present in higher amounts (lauric acid, palmitic acid, linolenic acid etc.) would have a bigger influence on this property. Since azelaic acid can inhibit the reproduction of lipophilic microorganisms in skin sebaceous glands, it can help to protect insect lipids from infections [84]. One of the most abundant fatty acids in BSFL is lauric acid $[21,43,45,56]$. The latter could also be converted into monolaurin (or glycerol monolaurate), which is an antiviral, antibacterial, and antiprotozoal glyceride for animals and humans [85], and this could explain a hypothetical anti-bacterial activity of BSF lipids [86]. Spranghers et al. [21] found that lipids of BSF prepupae were mostly composed of lauric acid, even when BSFL feed on substrate with an extremely low percentage of the above-mentioned acid. It means that the fatty acids composition of the rearing diet did not directly affect the larval fatty acids composition, which, on the contrary, was more influenced by carbohydrates [21,67]. The conversion of carbohydrates into lipids by insects has been well documented $[79,87,88]$. As demonstrated for other Diptera species, the BSF larval fatty acid profile is composed mainly of saturated fats like lauric acid, myristic acid, palmitic acid, and stearic acid [21,80]. As reported by Bennett and Lee [89], insects with less adaptation to low temperatures show a high presence of saturated fatty acids. Indeed, BSF has difficulty with cold adaptation, demonstrated by the lowest survival rate 
at about $16{ }^{\circ} \mathrm{C}$ [90]. Currently, lauric acid is mainly extracted from vegetable matrices (coconut oil and palm kernel oil) and, for its antimicrobial properties, it is commercially used as a primary component for the preparation of several products for personal care (soaps, detergents, and shampoos) [91-94]. The use of lauric acid obtained from alternative sources, such as insect lipids, may replace the main common sources (palm kernel oil, coconut oil) and contribute to the conservation of tropical forests [43]. The high content of the aforementioned acid in BSF prepupae could be an interesting extra element to support the proposal of the inclusion of BSFL or prepupae in poultry and pig feed considering the faster and more efficient absorption and metabolism of short chain fatty acids (such as lauric acid) compared to long chain fatty acids and their nutraceutical potential [21,95]. In addition, Skrivanova et al. [96] showed that, among the valuable short chain fatty acids, lauric acid had the highest activity against the pathogen Clostridium perfringens and the lowest impact on the beneficial bacteria Lactobacilli. In light of beneficial effects on intestinal health and microbial growth inhibition, lauric acid could improve the performance and welfare of farm animals [21]. Considering that the use of antibiotics for non-medical applications was banned by the EU (Regulation 1831/2003/EC) [97], lauric acid could be used as an alternative to in-feed antibiotics for controlling microbial infections [97-99]. Concerning toxic elements that could influence the nutritional value of animal feed, the noxious erucic acid in BSFL fatty acids profile never exceeded 1.3\%, regardless of the administered diet [43]. The admitted concentration of erucic acid in food and feed was limited by the EFSA (European Food Safety Authority) in 2016 to a tolerable daily intake (TDI) of $7 \mathrm{mg} / \mathrm{kg}$ body weight [100]. On the other hand, the low amount of polyunsaturated fatty acids (PUFA) $\mathrm{n}-3$ in the BSFL could limit their application as animal feed ingredients [77]. Indeed, the use of full-fat insect meals with a high fat content, as BSF meal, corresponds to a decrease in the nutritional quality of animal products [101-103]. However, BSFL can be enriched in PUFA n-3, modulating the feeding substrate. Crude fat of BSFL frequently contains some non-triacylglycerol components including gummy matter, oxidized intermediates, fatty acids, odorous residue, colour compounds, and pigments which can negatively affect taste, nutritional value and appearance. Hence, it is necessary to remove some of these components during the extraction process to get lipids as pure as possible and to avoid undesirable characteristics (with less proteins, less turbidity, density, and viscosity) before their application in the cosmetic and/or food applications [49]. Anyway, depending on the projected aims (animal feed, biodiesel production), the qualitative fatty acid composition of lipids in BSFL can be modified according to the different organic substrates selected for the insect feed [21,43], as reported in Table S2.

\section{Lipid Extraction}

The lipid extraction and subsequent fractionation require the use of organic solvents and techniques not used in the purification of water-soluble molecules such as proteins and carbohydrates [104-106]. Polarity and solubility of lipids in non-polar solvents are the main characteristics to separate complex lipid mixtures [104]. Lipids that contain fatty acids bound with ester or amide bonds can be hydrolyzed with acids, alkalis, or with hydrolytic enzymes. Neutral lipids such as triacylglycerols, pigments, and waxes can be extracted with ether, chloroform and benzene [106]. Membrane lipids are more easily extracted by polar organic solvents such as methanol and ethanol since they reduce the hydrophobic interactions between the lipid molecules and weaken the hydrogen bonds and the electrostatic interactions that bind lipids to membrane proteins [106].

The procedure to extract lipids from animals or plants involves several steps:

- $\quad$ sample reduction, drying or hydrolysis;

- $\quad$ sample homogenization with organic solvent;

- separation of the organic and aqueous phase (organic phase contains lipids);

- removal of non-lipid contaminants (if necessary);

- drying of the extract to remove the organic solvent. 
It is not possible to use a single standard method for the extraction of all types of lipids [107] since each matrix has different characteristics and therefore different approaches must be used [108].

In the lipid extraction procedure, the first aspect to consider concerns the size of the sample [109]. Small particle size increases the surface that allows better contact with the organic solvent, raising its extractive yield [110]. Even if lipids are not soluble in water, the presence of this molecule is also not completely negligible as it influences the extraction capacity of the solvent $[110,111]$. Organic solvents, such as diethyl ether or hexane, do not easily penetrate the tissues and a complete lipid extraction does not always occur [112]. On the other hand, more water usage in the extraction may lead to higher costs, as the solute separation requires a lot of energy by using water as a solvent $[109,113]$. A common treatment is acid or basic hydrolysis, which makes lipids more accessible to the organic solvent that is required to split lipids from proteins or carbohydrates and to break down emulsified fats [114].

The type of solvent and the extraction method depend on the chemical structure of the sample and the type of lipid that must be extracted. An important characteristic of the solvent is the high solubility for lipid compounds and the poor solubility for amino acids, proteins and carbohydrates. Solvents tend to deactivate enzymes and also prevent unwanted reactions. The solvent must easily penetrate the sample particles and must have a low boiling point to easily evaporate. The most commonly used solvents are alcohols (such as ethanol, methanol, and n-butanol), acetonitrile, acetone, halogenated hydrocarbons (chloroform, dichloromethane), ethers, hydrocarbons (benzene, hexane), or a mixture of them [115].

\subsection{Traditional Lipid Extraction Methods}

The methods described below (Figure 3) can be applied for lipid extraction from different cell typologies (both animals and vegetables) [116].

\section{LIPIDS EXTRACTION METHODS}

FOLCH METHOD

Chloroform-methanol
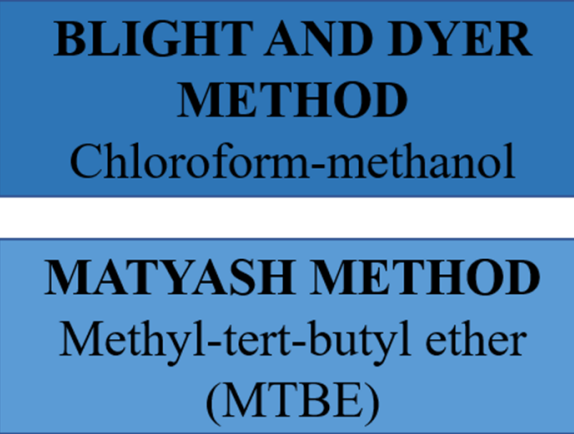

TPP METHOD Tert-butanol + ammonium sulphate
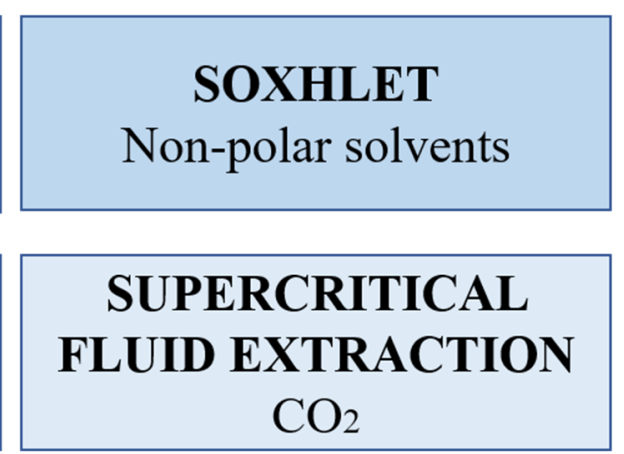

Figure 3. Several methods for lipid extraction have been developed so far: the Folch method, the Bligh and Dyer method, the Matyash method, the TPP method, the Soxhlet method, and the Supercritical fluid extraction method. 
The Folch method is a traditional method used for the extraction of lipids from brain tissue. It consists of two steps in which the tissue, in a 1:20 ratio with the solvent, is homogenized with a 2:1 v/v mixture of chloroform-methanol. The filtrate is then treated with water, with the possible addition of salts, obtaining two phases where the lower one contains lipids while the upper phase contains non-lipid substances [117]. A modified Folch method has been adopted by several extraction protocols.

The Matyash et al. [118] method consists in a modification of the Folch/Bligh and Dyer methods and allows a better recovery of almost all the main classes of lipids. Methyltert-butyl ether (MTBE) is used as a solvent for the extraction and allows for the obtaining of a more accurate lipid profile. Solvents containing chlorine, including chloroform, should be avoided [119], as they lead to the formation of a protein interphase between the polar and the lipid phase. MTBE is an appropriate alternative to chloroform [120]. In this protocol, the sample is mixed with 7.5 volumes of methanol and 25 volumes of MTBE, and the extracted lipids can be directly used for subsequent investigations or stored in a chloroform/methane/water mixture (60/30/4.5, v/v/v).

The TPP method (or three-phase partitioning) was initially designed by Dennison and Lovrien Rex [121] for the extraction of proteins. The method involves the use of a solution containing tert-butanol and water. The subsequent addition of ammonium sulphate induces the formation of two phases: a lower aqueous phase containing the salt and an upper one containing the alcohols. If proteins are present in the aqueous solution, they precipitate at the interface of the two phases. The top layer of tert-butanol contains membrane lipids and other low molecular weight molecules [122].

The Soxhlet method allows for the determination of the raw lipid content by extracting the lipids from the sample with consecutive gravimetric measurements. It is a system of continuous extraction in which the sample is placed into a thimble inside an extractor called a "Soxhlet extractor". The solvent is generally a non-polar liquid such as petroleum ether and hexane. The flask containing the solvent is heated and the solvent that evaporates is conveyed into the extraction pocket which is connected to a cooling system and to the distillation flask. When completed, the solvent has evaporated and the flask contains the dry lipid residue $[123,124]$.

The supercritical fluid extraction method involves a supercritical fluid, carbon dioxide $\left(\mathrm{CO}_{2}\right)$, as a solvent. A supercritical fluid is formed every time a substance is heated beyond its critical temperature, above which the substance cannot be condensed in its liquid state through the simple application of a pressure [125]. The $\mathrm{CO}_{2}$ is heated in a pressurization chamber and the lipid component is contained in a new formed layer which is separated from the aqueous component. The $\mathrm{CO}_{2}$ is subsequently removed by expansion at room pressure. The supercritical fluid extraction method is particularly advantageous for processing food products [126] and has several advantages, including reduced oxidation of solutes, the possibility of extraction of components sensitive to high temperatures, the modulation of extractive conditions, extracts that are removed without solvent, and desirable solvent conditions such as non-toxicity and non-explosiveness.

\subsection{Industrial Extraction Method}

The industrial extraction of fats from fresh or dried larvae follows different methodologies compared to traditional extraction [127].

The BSFL dried biomass is pressed to obtain fat and partially defatted meals. This extraction involves a screw press, which works at $100{ }^{\circ} \mathrm{C}$ and is typically used in oil extractions of nuts and seeds. During the process, the fat from larvae squeezes out and a press cake is produced. BSFL protein meal is yielded from the press cake and BSFL fat from the press liquid after further filtration processes. There are two different methods for fractioning BSFL using a screw press: dry processing and wet processing. The first one involves a drying process of BSFL before pressing while in the second method, fresh BSFL are directly pressed. The press cake can be grinded into BSFL protein meal directly and the crude BSFL fat can be further refined by a filtration or decanting step. Fat refining 
separates the fat from solids, which can account for up to $40 \%$ of the mass of crude BSFL fat. For the wet process, a further drying and grinding of the press cake is required to reduce its moisture content and particle size. The separation of the press liquid is more difficult and advanced equipment would be needed. However, the processing time for fresh larvae takes more time. The microwave-dried larvae are very light and easy to press, whereas wet larvae are heavy and not only fat but also have water which has to be released and therefore increases the processing time.

\section{Black Soldier Fly Lipid Applications}

Currently, the study and the research of new materials that have low environmental impact and are safe for humans is of crucial importance. Research is driven not only by the reduction of fossil resources, but also by the impact of human activities on the planet, such as waste production and the excessive depletion of natural resources. The industry is using vegetable oils as an alternative to fossil fuels, but their environmental impact is still a serious problem [128]. Since the demand for vegetable oils and biofuels contributes to tropical deforestation, habitat fragmentation and loss of biodiversity, the use of insectderived fats could be the most sustainable choice to consider. Insects are organisms with high potential thanks to their countless applications in several sectors. This review focused on the usage of BSFL-derived lipids in biodiesel production and animal feed (Figure 4).
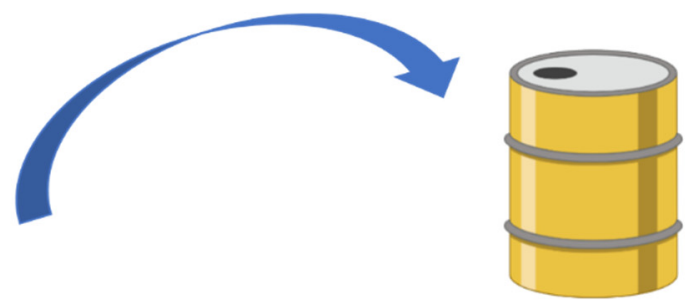

\section{Biodiesel}
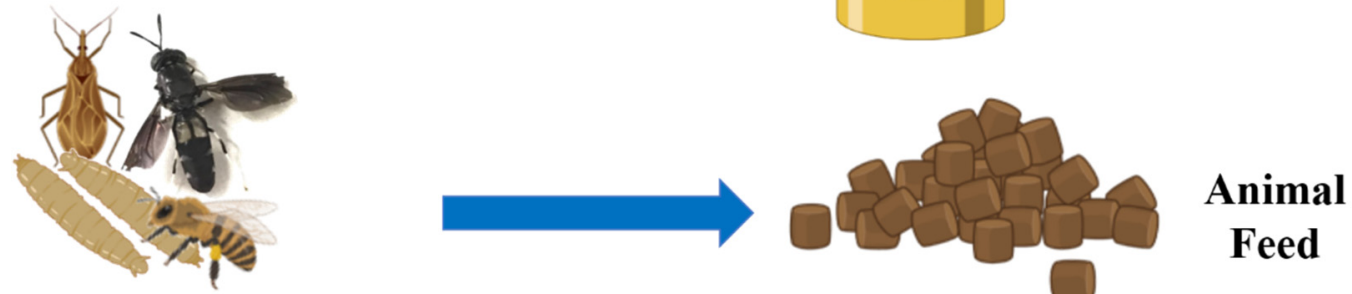

\section{Insects}

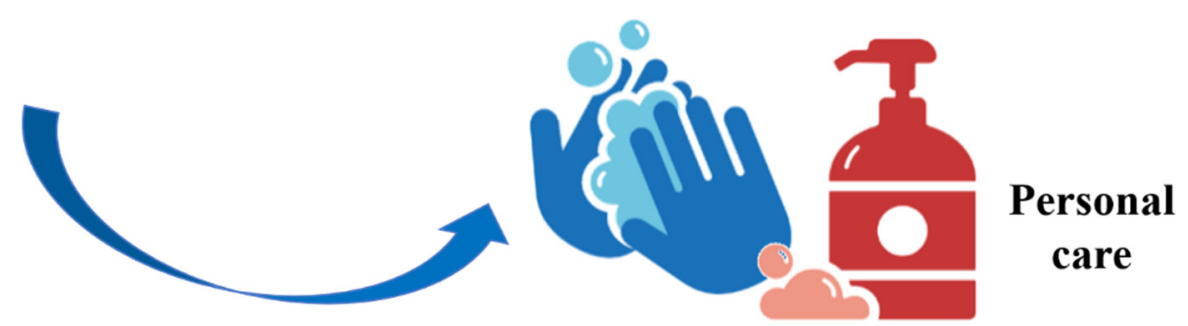

Figure 4. Main applications of insect lipids: biodiesel production, animal feed and personal care.

\subsection{Biodiesel Production}

Since the last century, fossil fuels have been used to meet the energy demands for economic development. Currently, climate issues and the reduction of non-renewable fossil resources have motivated the development of renewable energies such as solar, wind, and biomass. Among renewable energies with low environmental impact, liquid biofuels, such as bioethanol and biodiesel, can be used in current engines [129] and regular diesel engines [130]. In addition, biodiesel is predominantly used as an additive to traditional fuel in order to minimize the release of particulates, carbon monoxide, and hydrocarbons [131]. The main obstacle preventing biodiesel usage as a primary fuel is represented by the production cost. It has been shown that $75 \%$ of biodiesel cost derives from the feedstock, such as vegetable oil, starch, or animal fats [132]. The biodiesel production 
process involves two steps: an acid-catalysed esterification of free fatty acids of the crude oil as pre-treatment, and their alkaline-catalysed transesterification [132-134]. The latter process is used to convert the free fatty acids of the raw lipid extract into biodiesel and to reduce its acidity. The use of seed oils for biodiesel production is not a sustainable option, since they are an important food resource, especially for developing countries. A promising alternative to seed oils are microalgae, thanks to their high rate of lipid accumulation and fast growth [135-137], but their use is limited by high production costs and the less than optimal lipid composition [138] and, therefore, it is still insufficiently competitive. Thus, the biodiesel market needs to find new and innovative sources, particularly cheap and non-food-materials.

BSFL were investigated for biodiesel production by Li et al. [82]. Lipid production and the amount of biodiesel derived by BSFL fed for 10 days on different types of manure were evaluated. Samples of crude lipid extract were treated to esterify free fatty acids with methanol using $\mathrm{H}_{2} \mathrm{SO}_{4}(1 \% w / w)$ as a catalyst. The acid-catalysed esterification was performed in different conditions: using methanol in different ratios (from 6:1 to 12:1), at different exposure times (ranging from 30 to $120 \mathrm{~min}$ ), and at different temperatures (between $55^{\circ} \mathrm{C}$ and $85^{\circ} \mathrm{C}$ ). In the pre-treatment of acid-catalysed esterification of free fatty acids, the highest conversion rate of fatty acids was obtained with the ratio between methanol and insect fat at $8: 1$, and at a temperature of $75^{\circ} \mathrm{C}$ for $1 \mathrm{~h}$. The best result in terms of lipids production was obtained by feeding larvae on poultry manure: a crude fat yield of $30.1 \%$ was obtained from the larvae with a respective biodiesel yield of $93 \%$. Similar crude fat yields around $29 \%$ were obtained from larvae fed on both dairy and pig manure. The respective biodiesel yield was slightly higher from larvae fed on pig manure than from those fed on dairy manure (96\% vs. 93\%).

Characteristics of the biofuel produced by BSFL, such as iodine number, saponification value, melting point, peroxide value and acid value, density, viscosity, explosion point and cetane index, are similar to those of biodiesel produced with rapeseed oil, and are in accordance with the European biodiesel standard, EN14214 [68,132,138,139]. Furthermore, the biofuel produced from BSFL fat has greater oxidative stability than that produced by rapeseed oil because of the higher content of saturated ester methyl fatty acids (up to $67.6 \%)[132,138]$.

Zheng et al. [140] evaluated the biodiesel yield from both the organic waste fraction from restaurants and the BSFL fed on it. A yield of 3.3\% fat and $2.7 \%$ biodiesel was obtained from restaurant waste. By contrast, BSFL raised on this waste for seven days produced about 39\% lipids and a respective biodiesel yield of $25 \%$. This investigation demonstrated that it is possible to perform a double extraction: directly from the food residue, with a lower yield, and also from the larvae fed with the same organic substrate obtaining a higher quantity of extracted lipids with a better fatty acid profile. In addition, the weight of the restaurant organic waste was reduced by $61.8 \%$.

Another interesting study was undertaken by Surendra et al. [81] concerning the evaluation of the growth of larval biomass on human food waste. Lipid extraction from BSF prepupae was performed mechanically using a press. The larvae provided a lipid yield of $15-20 \%$ of dry product, i.e., only about $40 \%$ of the fat contained in the prepupae of BSF. This low fat yield was probably related to the low fibre content in BSF prepupae, which did not offer a sufficient back pressure during extraction. A subsequent extraction was carried out on the crude fat obtained with the Soxhlet method using petroleum ether as a solvent. The content of short chain saturated fatty acids (C12:0, C16:0) in the fat obtained from BSF prepupae $(67 \%)$ was higher than in soybean oil (13\%) and in palm oil $(37 \%)$. Hence, food residues used in this study can be considered an optimal substrate for the larval development and the subsequent lipid extraction and biodiesel production. Considering that a third of the food produced globally is not consumed by humans but rather thrown away, its use as a feeding substrate for the biodiesel production from livestock can contribute to the reduction of greenhouse gas emissions and economic losses [22,141]. 
Another unconventional raw material for biodiesel production was studied by Li et al. [68]. They investigated the accumulation of lipids and the following biodiesel production from BSFL fed on glucose and xylose from lignocelluloses. Xylose and glucose, in individual or mixed form, were effectively metabolized into lipids stored in BSFL. The addition of $6 \%$ xylose to the standard larval diet led to a yield of $34.6 \%$ of extracted lipids, encouraging the use of BSF for the conversion of lignocellulose into biodiesel [68].

Wong et al. [142] analysed new conditions to increase the biodiesel yield from fats extracted from BSFL. Larvae reared on a substrate containing coconut endosperm with the addition of microorganisms to promote fermentation were tested. The amount of total fat and lipid composition for the fifth and sixth larval instars were evaluated. The lipid content in the fifth instar was $34 \%$, while that in the sixth instar was $26 \%$. No differences in terms of composition in fatty acid methyl esters (FAME) were found. The yield in terms of FAME was $25 \%$ in the sixth instar and 33\% in the fifth instar, reaching 38.5\% with the addition of $0.5 \%$ of yeast powder to the substrate. The addition of yeast had positive effects on the conversion rate of the food substrate thanks to an in-situ fermentation. The protein content of the larvae was also improved, while no changes were found for the quantity and composition of lipids.

As described in a paper by Nguyen et al. [133], a direct transesterification technique with fewer steps was proposed to reduce energy costs. In this method, the key element is methanol, which is simultaneously used as a solvent for extraction of fat and as a reagent for the transesterification of the extracted fatty acids into methyl ester fatty acids. Recently, to reduce methanol usage [143], cosolvents such as hexane, pentane, chloroform, acetone and petroleum ether, which increase extraction efficiency because of their ability to dissolve long-chain triglycerides, have been proposed $[133,143,144]$. Among the solvents used, hexane allowed the highest yield (63.37\%) and was found to be the perfect co-solvent for lipid extraction and biodiesel production from BSFL. Subsequently, several experiments were performed with different solvents, methanol volume ratios (v:v), different solvent dosages, temperature conditions and reaction times, with the aim to establish their effect on biodiesel yield. The results revealed that the biodiesel yield increased with the solvent dosage, reaction time, temperature and with lower hexane: methanol volume ratios, most likely because an excess of solvent decreases the collision between grease and methanol [143]. Sulfuric acid catalyses the transesterification reaction of acylglycerols and the esterification reaction of free fatty acids $[139,143,145]$, but large quantities of sulfuric acid (higher than $1.2 \mathrm{~mL}$ ) can cause polymerization of unsaturated fatty acids, leading to a reduction of the biodiesel yield $[98,143,146]$. The amount of biodiesel increased with temperature but there was no substantial growth above $120^{\circ} \mathrm{C}$; therefore, $120^{\circ} \mathrm{C}$ was chosen as the optimal temperature for biodiesel production. The highest biodiesel yield $(94.14 \%)$ on total fat content was obtained at $120^{\circ} \mathrm{C}$ with a $1: 2$ hexane: methanol ratio $(v / v)$, a solvent dosage of $12 \mathrm{~mL}$, and a reaction time of $90 \mathrm{~min}$. Total lipid percentage, extracted from BSFL using hexane as a solvent, was $30.2 \%$. These results showed a concordance with the optimal characteristics of biofuels, these being water content, density values, acid value, sulphur content, and viscosity comparable to the European standard for biodiesel (EN1421), the international standard of the American Society for Test and Materials (ASTM) D6751 $[147,148]$, and to the biodiesel obtained from rapeseed oil. BSFL fat can be generally considered an optimal source to produce biodiesel with low viscosity and high oxidative stability thanks to a lipid profile rich in short-chain saturated fatty acids and low polyunsaturated fatty acids $[81,101]$. The process also leads to a considerable reduction in time, going from $49 \mathrm{~h}$ of traditional processes to $1.5 \mathrm{~h}$ [133].

Energy consumption analysis of lipid extraction from BSF biomass was carried out by Feng et al. [149]. The main process that shows high energy cost for insect lipid extraction is the dehydration of larvae, since the larvae can contain up to $70 \%$ water. The costs include the energy necessary to heat the homogenized larval biomass and to evaporate the contained water. The homogenization treatment before drying is used to break cell-cell bonds and to increase the flow of water $[98,150]$. The presence of water acts as a barrier to 
the transfer of the lipid component to the solvent, reducing its extraction efficiency $[110,111]$. Hence, to reduce the costs there is a need to reduce drying costs. The combined use of dehydration techniques reduces the energy cost by pre-treatment of insect biomass. For example, an initial centrifugation process reduces the amount of water present in the homogenized larvae from $70 \%$ to $30 \%$, and a subsequent heating reduces the percentage to $10 \%$ [149]. The combination mode has shown lower energy consumption. The mechanical process, rather than thermal alternatives such as centrifuge, vacuum filtration and vacuum drying, has a lower energy cost but requires longer times, and there is no existing evaluation on a large-scale production. Indeed, industrial-scale research on biorefinery and available data on massive extraction are lacking [151].

Other costs are related to the solvent used in the process. In general, the fat yield increases as the volume of solvent increases [133], but there are significant costs associated with the extraction processes.

It can be concluded that a promising alternative is represented by BSFL lipids, and these have become the current focus of several research works $[138,152]$.

Further knowledge is needed to improve the conversion rate of food residues into biomass, to increase the lipid yield and the transesterification rate of the fat extracted into biodiesel.

\subsection{Animal Feed}

Insects can be used as an ingredient in poultry, pig and aquaculture feeds $[21,23,62]$. In 2050, the demand for animal products is expected to increase by $60-70 \%$ [62]. To date, the cost of soy and fish feed is very high and their availability in the future may be limited [153]. When processed, insects provide the protein fraction and the fat fraction, both of great interest in the production of feed for aquaculture. Both living larvae and larval meal can be used as feed, even if meal is preferred for its easier transport and storage. The use of live insects can be economically sustainable but there is a high risk of escape and colonization of the surrounding ecosystems [154].

BSF is one of the promising species whose larvae have a high nutritional value and, therefore, they are ingredients of animal feedstuff, particularly for aquaculture [36]. It is known that diets containing BSFL are as palatable as those containing soy [62].

For many years, BSF meals such as fish feed have been tested for different species of fish. To include BSF meal as a substitute for soybean and fish meal in the diets of fish species, different features were analysed (growth performance, nutrient digestibility, and meat quality). The fish species studied are reported in Table S3.

Belghit et al. [155] evaluated the effect of dietary meal and fat from BSF on body composition, growth performance and nutrient digestibility of Atlantic salmon. It has been shown that it is possible to add up to $600 \mathrm{~g}$ of insect meal per $\mathrm{kg}$ of diet, in combination with insect fat, in Atlantic salmon diets without any negative impact on food intake, growth performance or feed conversion ratio (the ratio between the taken food and the gained weight).

St-Hilaire et al. [156] and Barroso et al. [157] demonstrated how to enrich BSFL in omega 3 fatty acids by means of dietary modifications. Specifically, prepupae that included fish offal in their diet were enriched in omega 3 fatty acids, especially $\alpha$-linolenic acid (ALA), eicosapentaenoic acid (EPA) and docosahexaenoic acid (DHA). These BSF prepupae may be used to reduce animal waste and recycle omega 3 fatty acids, and, simultaneously, to produce high-quality animal foodstuff, as they are a suitable replacement for fish meal and fish oil in animal diets.

The intake of $\omega 3$ could be improved by adding $\omega 3$ to the diet $[158,159]$ and, in general, the content of EPA and DHA in insect meal can be increased by nutritional management [157]. The bioaccumulation of the two fatty acids in insect larvae has nutritional relevance for humans $[157,160]$ and adds a great nutritional value to promote the use of insect meal as food. Moreover, according to Barroso et al. [157], the larvae fed with fish offal need short times of feeding to get enrichment of molecules such as EPA and DHA; 
specifically, the time was valued between $30 \mathrm{~min}$ and $3 \mathrm{~h}$ before harvesting. However, if the aim is to get larvae with high values of $\omega 3$ to feed animals, the enrichment of the feeding substrate is not convenient; providing $\omega 3$ directly to the animals could be simpler and cheaper.

Meals obtained from BSFL find application in the feeding of growing pigs because of the high amino acid, lipid and calcium contents [161]. A study by Nekrasov et al. [162] focused on the use of BSFL fats applied to the feeding of farmed pigs. Pigs fed with a standard diet (administered ad libitum) with the addition of $0.3 \%$ and $0.9 \%$ BSFL showed a higher average daily weight gain (between $8.2 \%$ and $9.1 \%$ ) than the control group fed with a standard substrate. Pigs fed with supplemented BSFL also showed an increase of total protein concentration, leukocytes and bifid bacteria, a reduction in bilirubin level and no variations of lactobacilli in the large intestine when compared to the control group. Moreover, in the experimental group, where no type of antibiotic was used, survival of pigs was $100 \%$ compared to the control group in which pigs' survival was $98 \%$, using antibiotics when necessary. This study demonstrated the possibility to use BSFL as a dietary supplement for growing pigs and that BSF can be a source of valuable biomolecules with a positive impact on animal immune system [162].

Yu et al. [163] showed that inclusion of BSFL in feedstuff for pigs had a beneficial effect on growth performance and meat quality. Four groups of pigs, weaned at 21 days, were fed with a supplementation $(0 \%, 1 \%, 2 \%$ and $4 \%$ ) of BSFL meal with full fat content. Two experimental feeding phases were tested: days 1-14 and days 15-28. Results revealed no mortality and no increase of diarrhoea manifestation induced by insect meal. Generally, a $2 \%$ supplementation of the BSFL meal had a significant positive effect on the growth performance and organ weight of the pigs.

A similar study was performed by Heugten et al. [164], who evaluated the impact of supplementing the diet with increasing amounts of BSFL fat on the growth and performance of 21 day old, weaned pigs. Zero, $2 \%, 4 \%$, and $6 \%$ of supplemental insect fat was used as a replacement for equal quantities of corn oil. The addition of insect lipids led to an increase of both the weight and the gain/feed ratio (that means the weight gain in relation to the percentage of BSFL fat in diet) of the pigs.

Furthermore, BSF meal as a poultry feed has been largely investigated [16,165-181]. Most of the studies showed that it is possible to replace a considerable part of the soybean meal in poultry diets with BSF meal without negatively affecting performance and the quality of the final products [182]. The results of the effect of BSF feed on poultry are not univocal because different factors are involved, including the animal growth stage, the breed (broiler or layer), the method of feed administration, the inclusion rate of BSF meal in the standard diet, the feeding substrate of BSFL used as meal, BSF-feeding duration and the method of processing the BSFL [182]. For example, between the treatment containing up to $15 \%$ of BSF biomass and the control diets in terms of apparent assimilation of nutrients, feeding preference, carcass traits, productive performance, index of mortality, and sensory and meat quality characteristics while feeding chicken, no significant difference was observed $[165,177,183]$. Similarly, BSF meal in the diets of layers have not shown consistent results $[16,167,184,185]$. Moreover, replacement in a short period did not affect the performance of laying hens $[16,184,186]$, and in a longer period negatively affected their performance $[16,167,184]$. On the other hand, the use of lipids only as additives to the poultry diet has recently been studied. Kim et al. [186] have performed a study on farmed chickens comparing standard substrate with an integration of three sources of fats: corn oil, coconut oil, and BSFL fat. The aim of the study was to observe the effect of the fat addition on growth performance, carcass characteristics, composition of body fatty acids, production of volatile fatty acids and serum parameters in chickens. During a feeding period of 30 days, $50 \mathrm{~g}$ of fat per $\mathrm{kg}$ of standard diet were added. The feed conversion ratio was lower with both the coconut oil and BSFL fat than with the corn oil. Insect fat changed the fatty acids composition of chickens, showing a significant increase of branched-chain fatty acids and short-chain fatty acids in the half feeding period. The fatty acid composition 
of abdominal fat was influenced by dietary fat sources. Particularly, chickens fed diets containing coconut oil or BSFL fat showed higher content of saturated fatty acids such as lauric and myristic acids, than those fed with an addition of corn oil. On the other hand, polyunsaturated fatty acids were higher with corn oil compared to both coconut oil and insect fat. Finally, a significant increase of the total antioxidant capacity in chickens fed with oil derived from BSFL compared to corn oil was observed. The supplement of BSFL fat improved the colour of the chicken breast, an important feature that highlights good nutrition in terms of quality of poultry feed, and this can be of additional value for the chicken meat market.

Overall, these studies suggest that the fat extracted from BSFL can be used as a functional lipid ingredient and that it has a positive effect on gut health, enriches medium-chain fatty acids in edible tissues, and increases antioxidant capacity in broilers $[161,164,187,188]$.

BSFL fat is a highly energetic food supplement in farmed animals that could provide a reduction in production costs through supplements made of insect flours or insect fats.

\section{Conclusions}

BSF contributes to the creation of a circular economy by bioconversion of different kinds of waste into biomass rich in proteins, lipids, chitin and several bioactive compounds. Lipids from BSF larvae can be used as a food and feed source, with a beneficial effect on animal growth performance and meat quality and a positive impact on animal immune systems. Moreover, they have applications in biodiesel production as innovative energysources in accordance with European biodiesel standards. The biodiesel production from BSFL fats needs further evaluation of results, techno-economical approaches, and evaluation of substrate accessibility; the large amount of needed fat for the biodiesel production is a limiting factor and a challenge for insect breeders. Despite the progress achieved so far, additional studies in the field are required for setting up standard protocols for insect fractions isolation, for improving the current procedures, and for investigating new and alternative applications of biomolecules from insect species. The main challenge in this regard is the implementation of BSFL breeding at an industrial scale, as there is a significant difference between benchtop and industrial scale results, and to deepen the knowledge on which applications fit better for this insect reared on different substrates and its derived valuable molecules.

Supplementary Materials: The following are available online at https:/ /www.mdpi.com/article/10 .3390/su131810198/s1. Table S1: Proximate lipid content of BSF biomass reared on different organic wastes (Unit: \% of dry matter); Table S2: Fatty acids profile of the BSF biomass reared on different organic waste (Unit: \% of dry matter); Table S3: Fish species fed with BSF. References [189-221] are cited in the Supplementary Materials.

Author Contributions: Conceptualization: P.F.; Writing—original draft preparation: P.F., A.F., C.S., R.S.; Writing - review and editing: A.F., C.S., R.S., A.M.P., E.T., A.M., E.S., P.F.; Supervision: P.F. All authors have read and agreed to the published version of the manuscript.

Funding: This research was supported by Basilicata Region within the frameworks of "Programma di Sviluppo Rurale 2014-2020" (projects “Valoriz.zoo" - measure 16.1, D.D. 14AE.2018/D.00092and "FeedInsect" - measure 16.2, D.D. 424/2019) and within the Innovative PhD Programme with specialization in enabling technologies in Industry 4.0.

Conflicts of Interest: The authors declare no competing interest.

\section{References}

1. Scudder, G.G.E. The Importance of Insects in Insect Biodiversity: Science and Society; Foottit, R.G., Adler, P.H., Eds.; Wiley Blackwell: Hoboken, NJ, USA, 2017.

2. Pires, C.S.S.; Maués, M.M. Insect pollinators, major threats and mitigation measures. Neotrop. Entomol. $2020,49,469-471$. [CrossRef]

3. Mauricio da Rocha, J.R.; De Almeida, J.R.; Lins, G.A.; Durval, A. Insects as indicators of environmental changing and pollution: A review of appropriate species and their monitoring. Holos Environ. 2010, 10, 250. [CrossRef] 
4. Cusumano, A.; Volkoff, A.N. Influence of parasitoid-associated viral symbionts on plant-insect interactions and biological control. Curr. Opin. Insect Sci. 2021, 44, 64-71. [CrossRef]

5. Adamski, Z.; Bufo, S.A.; Chowański, S.; Falabella, P.; Lubawy, J.; Marciniak, P.; Pacholska-Bogalska, J.; Salvia, R.; Scrano, L.; Słocińska, M.; et al. Beetles as model organisms in physiological, biomedical and environmental studies-A review. Front. Physiology 2019, 10, 319. [CrossRef]

6. Snell-Rood, E. Bring biologists into biomimetics. Nature 2016, 529, 277-278. [CrossRef]

7. Diener, S.; Zurbrügg, C.; Tockner, K. Conversion of organic material by black soldier fly larvae: Establishing optimal feeding rates. Waste Manag. Res. J. Sustain. Circ. Econ. 2009, 27, 603-610. [CrossRef] [PubMed]

8. Kalová, M.; Borkovcová, M. Voracious larvae Hermetia illucens and treatment of selected types of biodegradable waste. Acta. Univ. Agric. Silvic. Mendel. Brun. 2013, 61, 77-83. [CrossRef]

9. Zhou, F.; Tomberlin, J.K.; Zheng, L.; Yu, Z.; Zhang, J. Developmental and Waste Reduction Plasticity of Three Black Soldier Fly Strains (Diptera: Stratiomyidae) Raised on Different Livestock Manures. J. Med. Entomol. 2013, 50, 1224-1230. [CrossRef]

10. Sheppard, C. House Fly and Lesser Fly Control Utilizing the Black Soldier Fly in Manure Management Systems for Caged Laying Hens. Environ. Entomol. 1983, 12, 1439-1442. [CrossRef]

11. Nguyen, T.T.X.; Tomberlin, J.K.; Vanlaerhoven, S. Ability of Black Soldier Fly (Diptera: Stratiomyidae) Larvae to Recycle Food Waste. Environ. Entomol. 2015, 44, 406-410. [CrossRef]

12. Jucker, C.; Erba, D.; Leonardi, M.G.; Lupi, D.; Savoldelli, S. Assessment of Vegetable and Fruit Substrates as Potential Rearing Media for Hermetia illucens (Diptera: Stratiomyidae) Larvae. Environ. Entomol. 2017, 46, 1415-1423. [CrossRef]

13. Scala, A.; Cammack, J.A.; Salvia, R.; Scieuzo, C.; Franco, A.; Bufo, S.A.; Tomberlin, J.K.; Falabella, P. Rearing substrate impacts growth and macronutrient composition of Hermetia illucens (L.) (Diptera: Stratiomyidae) larvae produced at an industrial scale. Sci. Rep. 2020, 10, 19448. [CrossRef]

14. Webster, C.D.; Rawles, S.D.; Koch, J.F.; Thompson, K.R.; Kobayashi, Y.; Gannam, A.L.; Twibell, R.G.; Hyde, N.M. Bio-Ag reutilization of distiller's dried grains with solubles as a substrate for black soldier fly larvae, Hermetia illucens, along with poultry by-product meal and soybean meal, as total replacement of fish meal in diets for. Aquac. Nutr. 2016, 22, 976-988. [CrossRef]

15. Ruhnke, I.; Normant, C.; Campbell, D.L.M.; Iqbal, Z.; Lee, C.; Hinch, G.N.; Roberts, J. Impact of on-range choice feeding with black soldier fly larvae (Hermetia illucens) on flock performance, egg quality, and range use of free-range laying hens. Anim. Nutr. 2018, 4, 452-460. [CrossRef]

16. Engel, M.S. Insect evolution. Curr. Biol. 2015, 25, R868-R872. [CrossRef] [PubMed]

17. Ojha, S.; Bußler, S.; Schlüter, O.K. Food waste valorisation and circular economy concepts in insect production and processing. Waste Manag. 2020, 118, 600-609. [CrossRef]

18. Poshadri, A. Insects as an Alternate Source for Food to Conventional Food Animals. Int. J. Pure Appl. Biosci. 2018, 6, 697-705. [CrossRef]

19. FAO. Global Food Losses and Food Waste-Extent, Causes and Prevention. SAVE FOOD: An Initiative on Food Loss and Waste Reduction; FAO: Rome, Italy, 2011.

20. Fowles, T.M.; Nansen, C. Insect-Based Bioconversion: Value from Food Waste. In Food Waste Management; Springer International Publishing: Cham, Switzerland, 2020; pp. 321-346.

21. Spranghers, T.; Ottoboni, M.; Klootwijk, C.; Ovyn, A.; Deboosere, S.; De Meulenaer, B.; Michiels, J.; Eeckhout, M.; De Clercq, P.; De Smet, S. Nutritional composition of black soldier fly (Hermetia illucens) prepupae reared on different organic waste substrates. J. Sci. Food Agric. 2017, 97, 2594-2600. [CrossRef] [PubMed]

22. FAO. Agriculture Organization of the United Nations. Food Wastage Footprint: Impacts on Natural Resources; Summary Report; Natural Resources Management and Environment Department: Rome, Italy, 2013. Available online: http://www.fao.org/3/i3347e/i334 7e.pdf (accessed on 1 January 2021).

23. Xiao, X.; Jin, P.; Zheng, L.; Cai, M.; Yu, Z.; Yu, J.; Zhang, J. Effects of black soldier fly (Hermetia illucens) larvae meal protein as a fishmeal replacement on the growth and immune index of yellow catfish (Pelteobagrus fulvidraco). Aquac. Res. 2018, 49, 1569-1577. [CrossRef]

24. Commission Regulation (EU) 2017/893 of 24 May 2017 Amending Annexes I and IV to Regulation (EC) No $999 / 2001$ of the European Parliament and of the Council and Annexes X, XIV and XV to Commission Regulation (EU) No 142/2011 as Regards the Provisions on Processed Animal Protein (Text with EEA Relevance). Available online: https://eur-lex.europa.eu/legalcontent/EN/TXT/?uri=CELEX\%3A32017R0893 (accessed on 1 January 2021).

25. Gasco, L.; Biancarosa, I.; Liland, N.S. From waste to feed: A review of recent knowledge on insects as producers of protein and fat for animal feeds. Curr. Opin. Green Sustain. Chem. 2020, 23, 67-79. [CrossRef]

26. Marone, P.A. Food safety and regulatory concerns. In Insects as Sustainable Food Ingredients; Dossey, A.T., Morales-Ramos, J., Rojas, M.G., Eds.; Academic Press: Cambridge, MA, USA, 2016; pp. 203-221.

27. Van Huis, A.; Van Itterbeeck, J.; Klunder, H.; Mertens, E.; Halloran, A.; Muir, G.; Vantomme, P. Edible Insects: Future Prospects for Food and Feed Security; Food and Agriculture Organization of the United Nations: Quebec City, QC, Canada, 2013; Volume 97, ISBN 9789251075951.

28. Van Huis, A.; Oonincx, D.G.A.B. The environmental sustainability of insects as food and feed. A review. Agron. Sustain. Dev. 2017, 37, 43. [CrossRef] 
29. Cadinu, L.A.; Barra, P.; Torre, F.; Delogu, F.; Madau, F.A. Insect Rearing: Potential, Challenges, and Circularity. Sustainability 2020, 12, 4567. [CrossRef]

30. Madau, F.A.; Arru, B.; Furesi, R.; Pulina, P. Insect Farming for Feed and Food Production from a Circular Business Model Perspective. Sustainability 2020, 12, 5418. [CrossRef]

31. Tao, J.; Li, Y.O. Edible insects as a means to address global malnutrition and food insecurity issues. Food Qual. Saf. 2018, 2, 17-26. [CrossRef]

32. Mather, J.A. Ethics and care: For animals, not just mammals. Animals 2019, 9, 1018. [CrossRef] [PubMed]

33. EFSA Scientific Committee. Risk profile related to production and consumption of insects as food and feed. EFSA J. 2015, $13,4257$. [CrossRef]

34. Wanaratana, S.; Amonsin, A.; Chaisingh, A.; Panyim, S.; Sasipreeyajan, J.; Pakpinyo, S. Experimental assessment of houseflies as vectors in avian influenza subtype H5N1 transmission in chickens. Avian Dis. 2013, 57, 266-272. [CrossRef]

35. Pezzi, M.; Leis, M.; Chicca, M.; Falabella, P.; Salvia, R.; Scala, A.; Whitmore, D. Morphology of the antenna of Hermetia illucens (Diptera: Stratiomyidae): An ultrastructural investigation. J. Med Entomol. 2017, 54, 925-933. [CrossRef]

36. Newton, L.; Sheppard, C.; Watson, D.W.; Burtle, G.; Dove, R. Using the Black Soldier Fly, Hermetia illucens, as a Value-Added Tool for the Management of Swine Manure; Animal Poultry Waste Management Center, North Carolina State University: Raleigh, NC, USA, 2005; p. 17.

37. Purschke, B.; Scheibelberger, R.; Axmann, S.; Adler, A.; Jäger, H. Impact of substrate contamination with mycotoxins, heavy metals and pesticides on the growth performance and composition of black soldier fly larvae (Hermetia illucens) for use in the feed and food value chain. Food Addit. Contam. Part A 2017, 34, 1410-1420. [CrossRef]

38. Romdhana, M.H.; Lecomte, D.; Ladevie, B.; Sablayrolles, C. Monitoring of pathogenic microorganisms contamination during heat drying process of sewage sludge. Process. Saf. Environ. Prot. 2009, 87, 377-386. [CrossRef]

39. Regulation (EU) 2017/1017 of 15 June 2017 Amending Regulation (EU) No 68/2013 on the Catalogue of Feed Materials (Text with EEA Relevance). Available online: https:/ / eur-lex.europa.eu/legal-content/EN/TXT/PDF/?uri=CELEX:32017R1017\&from=EN (accessed on 1 January 2021).

40. Skrivervik, E. Insects' contribution to the bioeconomy and the reduction of food waste. Heliyon 2020, 6, e03934. [CrossRef] [PubMed]

41. Carpenter, F.M.; Burnham, L. The geological record of insects. Annu. Rev. Earth Planet. Sci. 1985, 13, 297. [CrossRef]

42. Lowman, M.D.; Rinker, H.B. Forest Canopies; Lowman, M.D., Rinker, H.B., Eds.; Elsevier: Amsterdam, The Netherlands, 2004.

43. Müller, A.; Wolf, D.; Gutzeit, H.O. The black soldier fly, Hermetia illucens-A promising source for sustainable production of proteins, lipids and bioactive substances. Z. Naturforsch. 2017, 72, 351-363. [CrossRef]

44. Ramos-Elorduy, J. Ecological Implications of Minilivestock-Potential of Insects, Rodents, Frogs and Sails; Paoletti, M.G., Ed.; CRC Press: Boca Raton, FL, USA, 2005; pp. 263-291.

45. Caligiani, A.; Marseglia, A.; Leni, G.; Baldassarre, S.; Maistrello, L.; Dossena, A.; Sforza, S. Composition of black soldier fly prepupae and systematic approaches for extraction and fractionation of proteins, lipids and chitin. Food Res. Int. 2018, 105, 812-820. [CrossRef]

46. Montowska, M.; Kowalczewski, P.Ł.; Rybicka, I.; Fornal, E. Nutritional value, protein and peptide composition of edible cricket powders. Food Chem. 2019, 289, 130-138. [CrossRef]

47. EFSA Panel on Nutrition, Novel Foods and Food Allergens (NDA); Turck, D.; Castenmiller, J.; De Henauw, S.; Hirsch-Ernst, K.I.; Kearney, J.; Maciuk, A.; Mangelsdorf, I.; McArdle, H.J.; Naska, A.; et al. Safety of dried yellow mealworm (Tenebrio molitor larva) as a novel food pursuant to Regulation (EU) 2015/2283. EFSA J. 2021, 19, e06343. [PubMed]

48. Triunfo, M.; Tafi, E.; Guarnieri, A.; Scieuzo, C.; Hahn, T.; Zibek, S.; Salvia, R.; Falabella, P. Insect Chitin-Based Nanomaterials for Innovative Cosmetics and Cosmeceuticals. Cosmetics 2021, 8, 40. [CrossRef]

49. Moretta, A.; Salvia, R.; Scieuzo, C.; Di Somma, A.; Vogel, H.; Pucci, P.; Sgambato, A.; Wolff, M.; Falabella, P. A bioinformatic study of antimicrobial peptides identified in the Black Soldier Fly (BSF) Hermetia illucens (Diptera: Stratiomyidae). Sci. Rep. 2020, 10, 16875. [CrossRef]

50. Moretta, A.; Scieuzo, C.; Petrone, A.M.; Salvia, R.; Manniello, M.D.; Franco, A.; Lucchetti, D.; Vassallo, A.; Vogel, H.; Sgambato, A.; et al. Antimicrobial Peptides: A New Hope in Biomedical and Pharmaceutical Fields. Front. Cell. Infect. Microbiol. 2021, 11. [CrossRef]

51. Manniello, M.D.; Moretta, A.; Salvia, R.; Scieuzo, C.; Lucchetti, D.; Vogel, H.; Sgambato, A.; Falabella, P. Insect antimicrobial peptides: Potential weapons to counteract the antibiotic resistance. Cell. Mol. Life Sci. 2021, 1, 3. [CrossRef]

52. Mai, H.C.; Dao, N.D.; Lam, T.D.; Nguyen, B.V.; Nguyen, D.C.; Bach, L.G. Purification Process, Physicochemical Properties, and Fatty Acid Composition of Black Soldier Fly (Hermetia illucens Linnaeus) Larvae Oil. J. Am. Oil Chem. Soc. 2019, 96, 1303-1311. [CrossRef]

53. Fasakin, E.A.; Balogun, A.M.; Ajayi, O.O. Evaluation of full-fat and defatted maggot meals in the feeding of clariid catfish Clarias gariepinus fingerlings. Aquac. Res. 2003, 34, 733-738. [CrossRef]

54. Delicato, C.; Schouteten, J.J.; Dewettinck, K.; Gellynck, X.; Tzompa-Sosa, D.A. Consumers' perception of bakery products with insect fat as partial butter replacement. Food Qual. Prefer. 2020, 79, 103755. [CrossRef]

55. Smetana, S.; Leonhardt, L.; Kauppi, S.-M.; Pajic, A.; Heinz, V. Insect margarine: Processing, sustainability and design. J. Clean. Prod. 2020, 264, 121670. [CrossRef] 
56. Leong, S.Y.; Kutty, S.R.M.; Tan, C.K.; Tey, L.H. Comparative study on the effect of organic waste on lauric acid produced by Hermetia illucens larvae via bioconversion. J. Eng. Sci. Technol. 2015, 8, 52-63.

57. Barragán-Fonseca, K.; Pineda-Mejia, J.; Dicke, M.; van Loon, J.J.A. Performance of the Black Soldier Fly (Diptera: Stratiomyidae) on Vegetable Residue-Based Diets Formulated Based on Protein and Carbohydrate Contents. J. Econ. Entomol. 2018. [CrossRef] [PubMed]

58. Barragan-Fonseca, K.B.; Dicke, M.; van Loon, J.J.A. Nutritional value of the black soldier fly (Hermetia illucens L.) and its suitability as animal feed-A review. J. Insects Food Feed 2017, 3, 105-120. [CrossRef]

59. Tschirner, M.; Simon, A. Influence of different growing substrates and processing on the nutrient composition of black soldier fly larvae destined for animal feed. J. Insects Food Feed 2015, 1, 249-259. [CrossRef]

60. Henry, M.; Gasco, L.; Piccolo, G.; Fountoulaki, E. Review on the use of insects in the diet of farmed fish: Past and future. Anim. Feed Sci. Technol. 2015, 203, 1-22. [CrossRef]

61. Leong, S.Y.; Kutty, S.R.M.; Malakahmad, A.; Tan, C.K. Feasibility study of biodiesel production using lipids of Hermetia illucens larva fed with organic waste. Waste Manag. 2016, 47, 84-90. [CrossRef]

62. Makkar, H.P.S.; Tran, G.; Heuzé, V.; Ankers, P. State-of-the-art on use of insects as animal feed. Anim. Feed Sci. Technol. 2014, 197, 1-33. [CrossRef]

63. Pieterse, E.; Pretorius, Q. Nutritional evaluation of dried larvae and pupae meal of the housefly (Musca domestica) using chemicaland broiler-based biological assays. Anim. Prod. Sci. 2014, 54, 347. [CrossRef]

64. Liu, C.; Wang, C.; Yao, H. Comprehensive Resource Utilization of Waste Using the Black Soldier Fly (Hermetia illucens L.) (Diptera: Stratiomyidae). Animals 2019, 9, 349. [CrossRef] [PubMed]

65. Gold, M.; Binggeli, M.; Kurt, F.; de Wouters, T.; Reichlin, M.; Zurbrügg, C.; Mathys, A.; Kreuzer, M. Novel Experimental Methods for the Investigation of Hermetia illucens (Diptera: Stratiomyidae) Larvae. J. Insect Sci. 2020, 20. [CrossRef] [PubMed]

66. Nguyen, T.T.X.; Tomberlin, J.K.; Vanlaerhoven, S. Influence of Resources on Hermetia illucens (Diptera: Stratiomyidae) Larval Development. J. Med. Entomol. 2013, 50, 898-906. [CrossRef]

67. Oonincx, D.G.A.B.; van Broekhoven, S.; van Huis, A.; van Loon, J.J.A. Feed Conversion, Survival and Development, and Composition of Four Insect Species on Diets Composed of Food By-Products. PLoS ONE 2015, 10, e0144601. [CrossRef] [PubMed]

68. Li, W.; Li, M.; Zheng, L.; Liu, Y.; Zhang, Y.; Yu, Z.; Ma, Z.; Li, Q. Simultaneous utilization of glucose and xylose for lipid accumulation in black soldier fly. Biotechnol. Biofuels 2015, 8, 117. [CrossRef]

69. Pimentel, A.C.; Montali, A.; Bruno, D.; Tettamanti, G. Metabolic adjustment of the larval fat body in Hermetia illucens to dietary conditions. J. Asia. Pac. Entomol. 2017, 20, 1307-1313. [CrossRef]

70. Danieli, P.P.; Lussiana, C.; Gasco, L.; Amici, A.; Ronchi, B. The Effects of Diet Formulation on the Yield, Proximate Composition, and Fatty Acid Profile of the Black Soldier Fly (Hermetia illucens L.) Prepupae Intended for Animal Feed. Animals 2019, 9, 178. [CrossRef]

71. Lalander, C.; Diener, S.; Zurbrügg, C.; Vinnerås, B. Effects of feedstock on larval development and process efficiency in waste treatment with black soldier fly (Hermetia illucens). J. Clean. Prod. 2019, 208, 211-219. [CrossRef]

72. Ewald, N.; Vidakovic, A.; Langeland, M.; Kiessling, A.; Sampels, S.; Lalander, C. Fatty acid composition of black soldier fly larvae (Hermetia illucens)-Possibilities and limitations for modification through diet. Waste Manag. 2020, 102, 40-47. [CrossRef] [PubMed]

73. Somroo, A.A.; ur Rehman, K.; Zheng, L.; Cai, M.; Xiao, X.; Hu, S.; Mathys, A.; Gold, M.; Yu, Z.; Zhang, J. Influence of Lactobacillus buchneri on soybean curd residue co-conversion by black soldier fly larvae (Hermetia illucens) for food and feedstock production. Waste Manag. 2019, 86, 114-122. [CrossRef] [PubMed]

74. Arango Gutiérrez, G.P.; Vergara Ruiz, R.A.; Mejía Vélez, H. Compositional, microbiological and protein digestibility analysis of the larva meal of Hermetia illuscens L. (Diptera: Stratiomyiidae) at Angelópolis-Antioquia, Colombia. Rev. Fac. Nac. Agron. Medellín 2004, 57, 2491-2500.

75. Yang, S.Y.; Li, W.J.; Liu, C.X.; Hu, W.F. Effects of fermented swine manure on the conversion ratio of Hermetia illucens and nutritional components detection of Hermetia illucens larva and sandworm. J. Anhui Agricul. Sci. 2016, 44, 69-70.

76. Julita, U.; Suryani, Y.; Kinasih, I.; Yuliawati, A.; Cahyanto, T.; Maryeti, Y.; Permana, A.D.; Fitri, L.L. Growth performance and nutritional composition of black soldier fly, Hermetia illucens (L), (Diptera: Stratiomyidae) reared on horse and sheep manure. In IOP Conference Series: Earth and Environmental Science; IOP Publishing: Bristol, UK, 2018; Volume 187, p. 012071.

77. Meneguz, M.; Schiavone, A.; Gai, F.; Dama, A.; Lussiana, C.; Renna, M.; Gasco, L. Effect of rearing substrate on growth performance, waste reduction efficiency and chemical composition of black soldier fly (Hermetia illucens) larvae. J. Sci. Food Agric. 2018, 98, 5776-5784. [CrossRef]

78. Arrese, E.L.; Soulages, J.L. Insect Fat Body: Energy, Metabolism, and Regulation. Annu. Rev. Entomol. 2010, 55, 207-225. [CrossRef]

79. Inagaki, S.; Yamashita, O. Metabolic shift from lipogenesis to glycogenesis in the last instar larval fat body of the silkworm, Bombyx mori. Insect Biochem. 1986, 16, 327-331. [CrossRef]

80. Ushakova, N.A.; Brodskii, E.S.; Kovalenko, A.A.; Bastrakov, A.I.; Kozlova, A.A.; Pavlov, D.S. Characteristics of lipid fractions of larvae of the black soldier fly Hermetia illucens. Dokl. Biochem. Biophys. 2016, 468, 209-212. [CrossRef] [PubMed]

81. Surendra, K.C.; Olivier, R.; Tomberlin, J.K.; Jha, R.; Khanal, S.K. Bioconversion of organic wastes into biodiesel and animal feed via insect farming. Renew. Energy 2016, 98, 197-202. [CrossRef] 
82. Li, Q.; Zheng, L.; Cai, H.; Garza, E.; Yu, Z.; Zhou, S. From organic waste to biodiesel: Black soldier fly, Hermetia illucens, makes it feasible. Fuel 2011, 90, 1545-1548. [CrossRef]

83. Kroeckel, S.; Harjes, A.G.E.; Roth, I.; Katz, H.; Wuertz, S.; Susenbeth, A.; Schulz, C. When a turbot catches a fly: Evaluation of a pre-pupae meal of the Black Soldier Fly (Hermetia illucens) as fish meal substitute-Growth performance and chitin degradation in juvenile turbot (Psetta maxima). Aquaculture 2012, 364, 345-352. [CrossRef]

84. Mashkovskii, M.D. Lekarstvennye Sredstva; Novaya Volna: Moscow, Russia, 2012.

85. Diclaro, J.W., II; Kaufman, P.E. Black Soldier Fly Hermetia Illucens Linnaeus (Insecta: Diptera: Stratiomyidae). Available online: https: / / edis.ifas.ufl.edu/pdf/IN/IN83000.pdf (accessed on 1 January 2021).

86. Almeida, C.; Rijo, P.; Rosado, C. Bioactive Compounds from Hermetia illucens Larvae as Natural Ingredients for Cosmetic Application. Biomolecules. 2020, 10, 976. [CrossRef] [PubMed]

87. Briegel, H. Metabolic relationship between female body size, reserves, and fecundity of Aedes aegypti. J. Insect Physiol. 1990, 36, 165-172. [CrossRef]

88. Venkatesh, K.; Morrison, P.E. Studies of weight changes and amount of food ingested by the stable fly, Stomoxys calcitrans (Diptera: Muscidae). Can. Entomol. 1980, 112, 141-149. [CrossRef]

89. Bennett, V.; Lee, R. Modeling seasonal changes in intracellular freeze-tolerance of fat body cells of the gall fly Eurosta solidaginis (Diptera, Tephritidae). J. Exp. Biol. 1997, 200, 185-192. [CrossRef]

90. Holmes, L.A.; VanLaerhoven, S.L.; Tomberlin, J.K. Lower temperature threshold of black soldier fly (Diptera: Stratiomyidae) development. J. Insects Food Feed 2016, 2, 255-262. [CrossRef]

91. Nakatsuji, T.; Kao, M.C.; Fang, J.-Y.; Zouboulis, C.C.; Zhang, L.; Gallo, R.L.; Huang, C.-M. Antimicrobial Property of Lauric Acid Against Propionibacterium Acnes: Its Therapeutic Potential for Inflammatory Acne vulgaris. J. Invest Dermatol. 2009, 129, 2480-2488. [CrossRef]

92. Park, K.-M.; Lee, S.J.; Yu, H.; Park, J.-Y.; Jung, H.-S.; Kim, K.; Lee, C.J.; Chang, P.-S. Hydrophilic and lipophilic characteristics of non-fatty acid moieties: Significant factors affecting antibacterial activity of lauric acid esters. Food Sci. Biotechnol. 2018, 27, 401-409. [CrossRef] [PubMed]

93. Zeiger, K.; Popp, J.; Becker, A.; Hankel, J.; Visscher, C.; Klein, G.; Meemken, D. Lauric acid as feed additive-An approach to reducing Campylobacter spp. in broiler meat. PLoS ONE 2017, 12, e0175693. [CrossRef]

94. Zhao, L.; Hu, Y.; Xu, D.; Cai, K. Surface functionalization of titanium substrates with chitosan-lauric acid conjugate to enhance osteoblasts functions and inhibit bacteria adhesion. Colloids Surf. B Biointerfaces 2014, 119, 115-125. [CrossRef] [PubMed]

95. Mohana Devi, S.; Kim, I. Effect of medium chain fatty acids (MCFA) and probiotic (Enterococcus faecium) supplementation on the growth performance, digestibility and blood profiles in weanling pigs. Vet. Med. 2014, 59, 527-535. [CrossRef]

96. Skřivanová, E.; Marounek, M.; Benda, V.; Březina, P. Susceptibility of Escherichia coli, Salmonella sp and Clostridium perfringens to organic acids and monolaurin. Veterinární Med. 2006, 51, 81-88. [CrossRef]

97. Regulation (EC) 1831/2003/EC on Additives for Use in Animal Nutrition, Replacing Directive 70/524/EEC on Additives in Feeding-Stuffs. Available online: https:/ / ec.europa.eu/jrc/sites/default/files/EC-1831-2003.pdf (accessed on 1 January 2021).

98. Kim, S.A.; Rhee, M.S. Highly enhanced bactericidal effects of medium chain fatty acids (caprylic, capric, and lauric acid) combined with edible plant essential oils (carvacrol, eugenol, $\beta$-resorcylic acid, trans -cinnamaldehyde, thymol, and vanillin) against Escherichia coli O1. Food Control. 2016, 60, 447-454. [CrossRef]

99. Spranghers, T.; Michiels, J.; Vrancx, J.; Ovyn, A.; Eeckhout, M.; De Clercq, P.; De Smet, S. Gut antimicrobial effects and nutritional value of black soldier fly (Hermetia illucens L.) prepupae for weaned piglets. Anim. Feed Sci. Technol. 2018, 235, 33-42. [CrossRef]

100. EFSA Panel on Contaminants in the Food Chain (CONTAM); Knutsen, H.K.; Alexander, J.; Barregård, L.; Bignami, M.; Brüschweiler, B.; Ceccatelli, S.; Dinovi, M.; Edler, L.; Grasl-Kraupp, B.; et al. Erucic acid in feed and food. EFSA J. 2016, $14, \mathrm{e} 04593$.

101. Bovera, F.; Loponte, R.; Marono, S.; Piccolo, G.; Parisi, G.; Iaconisi, V.; Gasco, L.; Nizza, A. Use of Tenebrio molitor larvae meal as protein source in broiler diet: Effect on growth performance, nutrient digestibility, and carcass and meat traits. J. Anim. Sci. 2016, 94, 639-647. [CrossRef]

102. Gasco, L.; Henry, M.; Piccolo, G.; Marono, S.; Gai, F.; Renna, M.; Lussiana, C.; Antonopoulou, E.; Mola, P.; Chatzifotis, S. Tenebrio molitor meal in diets for European sea bass (Dicentrarchus labrax L.) juveniles: Growth performance, whole body composition and in vivo apparent digestibility. Anim. Feed Sci. Technol. 2016, 220, 34-45. [CrossRef]

103. Renna, M.; Schiavone, A.; Gai, F.; Dabbou, S.; Lussiana, C.; Malfatto, V.; Prearo, M.; Capucchio, M.T.; Biasato, I.; Biasibetti, E.; et al. Evaluation of the suitability of a partially defatted black soldier fly (Hermetia illucens L.) larvae meal as ingredient for rainbow trout (Oncorhynchus mykiss Walbaum) diets. J. Anim. Sci. Biotechnol. 2017, 8, 1-13. [CrossRef]

104. Kates, M. Techniques of lipidology: Isolation, analysis and identification of lipids. In Laboratory Techniques in Biochemistry and Molecular Biology; Newport Somerville: Somerville, MA, USA, 1986.

105. Lee, A.G. Lipid-protein interactions in biological membranes: A structural perspective. Biochim. Biophys. Acta Biomembr. 2003, 1612, 1-40. [CrossRef]

106. Nelson, D.L.; Cox, M.M. Lehninger Principles of Biochemistry; Freeman, W.H.: New York, NY, USA, 2018.

107. Gil, A.; Zhang, W.; Wolters, J.C.; Permentier, H.; Boer, T.; Horvatovich, P.; Heiner-Fokkema, M.R.; Reijngoud, D.J.; Bischoff, R. One- vs two-phase extraction: Re-evaluation of sample preparation procedures for untargeted lipidomics in plasma samples. Anal. Bioanal. Chem. 2018, 410, 5859-5870. [CrossRef] 
108. Pomeranz, Y. Food Analysis: Theory and Practice; Pomeranz, Y., Ed.; Springer Science \& Business Media: Berlin/Heidelberg, Germany, 2013. [CrossRef]

109. Wongkittipong, R.; Prat, L.; Damronglerd, S.; Gourdon, C. Solid-liquid extraction of andrographolide from plants-Experimental study, kinetic reaction and model. Sep. Purif. Technol. 2004, 40, 147-154. [CrossRef]

110. Mohamad, M.; Ali, M.W.; Ripin, A.; Ahmad, A. Effect of Extraction Process Parameters on the Yield of Bioactive Compounds from the Roots of Eurycoma longifolia. J. Teknol. 2013, 60. [CrossRef]

111. Dong, T.; Knoshaug, E.P.; Pienkos, P.T.; Laurens, L.M.L. Lipid recovery from wet oleaginous microbial biomass for biofuel production: A critical review. Appl. Energy 2016, 177, 879-895. [CrossRef]

112. Pernet, F.; Tremblay, R. Effect of ultrasonication and grinding on the determination of lipid class content of microalgae harvested on filters. Lipids 2003, 38, 1191-1195. [CrossRef] [PubMed]

113. Ma, Y.-Q.; Chen, J.-C.; Liu, D.-H.; Ye, X.-Q. Simultaneous extraction of phenolic compounds of citrus peel extracts: Effect of ultrasound. Ultrason. Sonochem. 2009, 16, 57-62. [CrossRef] [PubMed]

114. Carpenter, D.E.; Ngvainti, J.N.; Lee, S. Lipid Analysis in: Methods of Analysis for Nutrition Labeling; Sulivan, D.M., Carpenter, D.E., Eds.; AOAC Press: Rockville, MD, USA, 1993; pp. 85-104.

115. Christie, W.W. Lipid Analysis; Pergamon Press: Oxford, UK, 1982.

116. Ranjith Kumar, R.; Hanumantha Rao, P.; Arumugam, M. Lipid Extraction Methods from Microalgae: A Comprehensive Review. Front. Energy Res. 2015, 2. [CrossRef]

117. Folch, J.; Lees, M.; Stanley, G.S. A simple method for the isolation and purification of total lipides from animal tissues. J. Biol. Chem. 1957, 226, 497-509. [CrossRef]

118. Matyash, V.; Liebisch, G.; Kurzchalia, T.V.; Shevchenko, A.; Schwudke, D. Lipid extraction by methyl-tert-butyl ether for high-throughput lipidomics. J. Lipid Res. 2008, 49, 1137-1146. [CrossRef]

119. Alfonsi, K.; Colberg, J.; Dunn, P.J.; Fevig, T.; Jennings, S.; Johnson, T.A.; Kleine, H.P.; Knight, C.; Nagy, M.A.; Perry, D.A.; et al. Green chemistry tools to influence a medicinal chemistry and research chemistry based organisation. Green Chem. 2008, 10, 31-36. [CrossRef]

120. Salem, M.; Bernach, M.; Bajdzienko, K.; Giavalisco, P. A Simple Fractionated Extraction Method for the Comprehensive Analysis of Metabolites, Lipids, and Proteins from a Single Sample. J. Vis. Exp. 2017. [CrossRef]

121. Dennison, C.; Lovrien, R. Three Phase Partitioning: Concentration and Purification of Proteins. Protein Expr. Purif. 1997, 11, 149-161. [CrossRef]

122. Dennison, C. Three-phase partitioning. In Methods in Protein Biochemistry; Tschesche, H., Ed.; de Gruyter: Berlin/Heidelberg, Germany, 2011; pp. 1-12.

123. Gómez-González, S.; Ruiz-Jiménez, J.; Priego-Capote, F.; Luque de Castro, M.D. Qualitative and Quantitative Sugar Profiling in Olive Fruits, Leaves, and Stems by Gas Chromatography-Tandem Mass Spectrometry (GC-MS/MS) after Ultrasound-Assisted Leaching. J. Agric. Food Chem. 2010, 58, 12292-12299. [CrossRef]

124. Isengard, H.D.; Morlock, G.; Breithaupt, D. Food Analysis in Food Science and Technology; Campbell-Platt, G., Ed.; Wiley: Hoboken, NJ, USA, 2017; pp. 31-75.

125. Skoog, D.A.; West, D.M.; Holler, F.J.; Crouch, S.R. Fundamentals of Analytical Chemistry; Nelson Education: Toronto, ON, USA, 2013.

126. Brunner, G. Supercritical fluids: Technology and application to food processing. J. Food Eng. 2005, 67, 21-33. [CrossRef]

127. Eawag-Aquatic Research. Fractioning of Black Soldier Fly Larvae into Protein Meal and Fat. Available online: https: // www.eawag.ch/fileadmin/Domain1/Abteilungen/sandec/schwerpunkte/swm/Practical_knowhow_on_BSF/bsf_ factsheet_fractioning.pdf (accessed on 1 January 2021).

128. Fitzherbert, E.; Struebig, M.; Morel, A.; Danielsen, F.; Bruhl, C.; Donald, P.; Phalan, B. How will oil palm expansion affect biodiversity? Trends Ecol. Evol. 2008, 23, 538-545. [CrossRef] [PubMed]

129. Demirbas, A. The importance of bioethanol and biodiesel from biomass. Energy Sources Part B Econ. Plan. Policy 2008, 3, 177-185. [CrossRef]

130. Islam, M.M.; Hasanuzzaman, M.; Pandey, A.K.; Rahim, N.A. Modern energy conversion technologies. In Energy for Sustainable Development; Hasanuzzaman, M., Rahim, N.A., Eds.; Academic Press: Cambridge, MA, USA, 2020; pp. 19-39.

131. Bozbas, K. Biodiesel as an alternative motor fuel: Production and policies in the European Union. Renew. Sustain. Energy Rev. 2008, 12, 542-552. [CrossRef]

132. Li, Q.; Zheng, L.; Qiu, N.; Cai, H.; Tomberlin, J.K.; Yu, Z. Bioconversion of dairy manure by black soldier fly (Diptera: Stratiomyidae) for biodiesel and sugar production. Waste Manag. 2011, 31, 1316-1320. [CrossRef] [PubMed]

133. Nguyen, H.C.; Liang, S.H.; Li, S.Y.; Su, C.H.; Chien, C.C.; Chen, Y.J.; Huong, D.T.M. Direct transesterification of black soldier fly larvae (Hermetia illucens) for biodiesel production. J. Taiwan Inst. Chem. Eng. 2018, 85, 165-169. [CrossRef]

134. Van Gerpen, J. Biodiesel processing and production. Fuel Process. Technol. 2005, 86, 1097-1107. [CrossRef]

135. Balat, M. Potential alternatives to edible oils for biodiesel production-A review of current work. Energy Convers. Manag. 2011, 52, 1479-1492. [CrossRef]

136. Mata, T.M.; Martins, A.A.; Caetano, N.S. Microalgae for biodiesel production and other applications: A review. Renew. Sustain. Energy Rev. 2010, 14, 217-232. [CrossRef] 
137. Pienkos, P.T.; Darzins, A. The promise and challenges of microalgal-derived biofuels. Biofuels Bioprod. Biorefin. 2009, 3, 431-440. [CrossRef]

138. Lee, A.F.; Bennett, J.A.; Manayil, J.C.; Wilson, K. Heterogeneous catalysis for sustainable biodiesel production via esterification and transesterification. Chem. Soc. Rev. 2014, 43, 7887-7916. [CrossRef]

139. Zheng, L.; Hou, Y.; Li, W.; Yang, S.; Li, Q.; Yu, Z. Exploring the potential of grease from yellow mealworm beetle (Tenebrio molitor) as a novel biodiesel feedstock. Appl. Energy 2013, 101, 618-621. [CrossRef]

140. Zheng, H.; Yang, X.; Xi, Y. Fat body remodeling and homeostasis control in Drosophila. Life Sci. 2016, 167, 22-31. [CrossRef]

141. Gustavsson, J.; Cederberg, C.; Sonesson, U.; Van Otterdijk, R.; Meybeck, A. Global Food Losses and Food Waste. 2011. Available online: http://www.fao.org/fileadmin/user_upload/suistainability/pdf/Global_Food_Losses_and_Food_Waste.pdf (accessed on 1 January 2021).

142. Wong, C.Y.; Aris, M.N.M.; Daud, H.; Lam, M.K.; Yong, C.S.; Hasan, H.A.; Chong, S.; Show, P.L.; Hajoeningtijas, O.D.; Ho, Y.C.; et al. In-situ yeast fermentation to enhance bioconversion of coconut endosperm waste into larval biomass of Hermetia illucens: Statistical augmentation of larval lipid content. Sustainability 2020, 12, 1558. [CrossRef]

143. Zhang, Y.; Li, Y.; Zhang, X.; Tan, T. Biodiesel production by direct transesterification of microalgal biomass with co-solvent. Bioresour. Technol. 2015, 196, 712-715. [CrossRef]

144. Rahimi, M.; Mohammadi, F.; Basiri, M.; Parsamoghadam, M.A.; Masahi, M.M. Transesterification of soybean oil in four-way micromixers for biodiesel production using a cosolvent. J. Taiwan Inst. Chem. Eng. 2016, 64, 203-210. [CrossRef]

145. Talebian-Kiakalaieh, A.; Amin, N.A.S.; Mazaheri, H. A review on novel processes of biodiesel production from waste cooking oil. Appl. Energy 2013, 104, 683-710. [CrossRef]

146. Sulaiman, S.; Abdul Aziz, A.R.; Aroua, M.K. Reactive extraction of solid coconut waste to produce biodiesel. J. Taiwan Inst. Chem. Eng. 2013, 44, 233-238. [CrossRef]

147. Ishak, S.; Kamari, A. A review of optimum conditions of transesterification process for biodiesel production from various feedstocks. Int. J. Environ. Sci. Technol. 2019, 16, 2481-2502. [CrossRef]

148. Su, C.H.; Nguyen, H.C.; Bui, T.L.; Huang, D.L. Enzyme-assisted extraction of insect fat for biodiesel production. J. Clean. Prod. 2019, 223, 436-444. [CrossRef]

149. Feng, W.; Xiong, H.; Wang, W.; Duan, X.; Yang, T.; Wu, C.; Yang, F.; Xiong, J.; Wang, T.; Wang, C. Energy consumption analysis of lipid extraction from black soldier fly biomass. Energy 2019, 185, 1076-1085. [CrossRef]

150. Yap, B.H.J.; Dumsday, G.J.; Scales, P.J.; Martin, G.J.O. Energy evaluation of algal cell disruption by high pressure homogenisation. Bioresour. Technol. 2015, 184, 280-285. [CrossRef] [PubMed]

151. Ravi, H.K.; Degrou, A.; Costil, J.; Trespeuch, C.; Chemat, F.; Vian, M.A. Larvae mediated valorization of industrial, agriculture and food wastes: Biorefinery concept through bioconversion, processes, procedures, and products. Processes 2020, 8, 857. [CrossRef]

152. Lai, E.P.C. Biodiesel: Environmental Friendly Alternative to Petrodiesel. J. Pet. Environ. Biotechnol. 2014, 5. [CrossRef]

153. Hua, K.; Cobcroft, J.M.; Cole, A.; Condon, K.; Jerry, D.R.; Mangott, A.; Praeger, C.; Vucko, M.J.; Zeng, C.; Zenger, K.; et al. The Future of Aquatic Protein: Implications for Protein Sources in Aquaculture Diets. One Earth 2019, 1, 316-329. [CrossRef]

154. Khusro, M.; Andrew, N.R.; Nicholas, A. Insects as poultry feed: A scoping study for poultry production systems in Australia. Worlds. Poult. Sci. J. 2012, 68, 435-446. [CrossRef]

155. Belghit, I.; Liland, N.S.; Waagbø, R.; Biancarosa, I.; Pelusio, N.; Li, Y.; Krogdahl, Å.; Lock, E.J. Potential of insect-based diets for Atlantic salmon (Salmo salar). Aquaculture 2018, 491, 72-81. [CrossRef]

156. St-Hilaire, S.; Sheppard, C.; Tomberlin, J.K.; Irving, S.; Newton, L.; McGuire, M.A.; Mosley, E.E.; Hardy, R.W.; Sealey, W. Fly prepupae as a feedstuff for rainbow trout, Oncorhynchus mykiss. J. World Aquac. Soc. 2007, 38, 59-67. [CrossRef]

157. Barroso, F.G.; Sánchez-Muros, M.-J.; Segura, M.; Morote, E.; Torres, A.; Ramos, R.; Guil, J.-L. Insects as food: Enrichment of larvae of Hermetia illucens with omega 3 fatty acids by means of dietary modifications. J. Food Compos. Anal. 2017, 62, 8-13. [CrossRef]

158. Belghit, I.; Liland, N.S.; Gjesdal, P.; Biancarosa, I.; Menchetti, E.; Li, Y.; Waagbø, R.; Krogdahl, Å.; Lock, E.J. Black soldier fly larvae meal can replace fish meal in diets of sea-water phase Atlantic salmon (Salmo salar). Aquaculture 2019, 503, 609-619. [CrossRef]

159. Belghit, I.; Waagbø, R.; Lock, E.J.; Liland, N.S. Insect-based diets high in lauric acid reduce liver lipids in freshwater Atlantic salmon. Aquac. Nutr. 2019, 25, 343-357. [CrossRef]

160. Cardoso, C.; Afonso, C.; Bandarra, N.M. Dietary DHA and health: Cognitive function ageing. Nutr. Res. Rev. 2016, 29, 281-294. [CrossRef]

161. Yu, M.; Li, Z.; Chen, W.; Rong, T.; Wang, G.; Ma, X. Hermetia illucens larvae as a potential dietary protein source altered the microbiota and modulated mucosal immune status in the colon of finishing pigs. J. Anim. Sci. Biotechnol. 2019, 10, 1-16. [CrossRef]

162. Nekrasov, R.; Zelenchenkova, A.; Chabaev, M.; Ivanov, G.; Antonov, A.; Pastukhova, N. PSIII-37 Dried Black Soldier Fly larvae as a dietary supplement to the diet of growing pigs. J. Anim. Sci. 2018, 96, 314. [CrossRef]

163. Yu, M.; Li, Z.; Chen, W.; Rong, T.; Wang, G.; Li, J.; Ma, X. Use of Hermetia illucens larvae as a dietary protein source: Effects on growth performance, carcass traits, and meat quality in finishing pigs. Meat Sci. 2019, 158, 107837. [CrossRef] [PubMed]

164. van Heugten, E.; Martinez, G.; McComb, A.; Koutsos, E. 285 Black soldier fly (Hermetia illucens) larvae oil improves growth performance of nursery pigs. J. Anim. Sci. 2019, 97, 118. [CrossRef]

165. Cullere, M.; Schiavone, A.; Dabbou, S.; Gasco, L.; Zotte, A.D. Meat quality and sensory traits of finisher broiler chickens fed with black soldier fly (Hermetia illucens L.) larvae fat as alternative fat source. Animals 2019, 9, 140. [CrossRef] 
166. Brede, A.; Wecke, C.; Liebert, F. Does the optimal dietary methionine to cysteine ratio in diets for growing chickens respond to high inclusion rates of insect meal from Hermetia illucens? Animals 2018, 8, 187. [CrossRef]

167. Cutrignelli, M.I.; Messina, M.; Tulli, F.; Randazzi, B.; Olivotto, I.; Gasco, L.; Loponte, R.; Bovera, F. Evaluation of an insect meal of the Black Soldier Fly (Hermetia illucens) as soybean substitute: Intestinal morphometry, enzymatic and microbial activity in laying hens. Res. Vet. Sci. 2018, 117, 209-215. [CrossRef] [PubMed]

168. Dabbou, S.; Gai, F.; Biasato, I.; Capucchio, M.T.; Biasibetti, E.; Dezzutto, D.; Meneguz, M.; Plachà, I.; Gasco, L.; Schiavone, A. Black soldier fly defatted meal as a dietary protein source for broiler chickens: Effects on growth performance, blood traits, gut morphology and histological features. J. Anim. Sci. Biotechnol. 2018, 9, 1-10. [CrossRef] [PubMed]

169. Lee, J.; Kim, Y.-M.; Park, Y.-K.; Yang, Y.-C.; Jung, B.-G.; Lee, B.-J. Black soldier fly (Hermetia illucens) larvae enhances immune activities and increases survivability of broiler chicks against experimental infection of Salmonella Gallinarum. J. Vet. Med. Sci. 2018, 80, 736-740. [CrossRef]

170. Kawasaki, K.; Hashimoto, Y.; Hori, A.; Kawasaki, T.; Hirayasu, H.; Iwase, S.I.; Hashizume, A.; Ido, A.; Miura, C.; Miura, T.; et al. Evaluation of black soldier fly (Hermetia illucens) larvae and pre-pupae raised on household organic waste, as potential ingredients for poultry feed. Animals 2019, 9, 98. [CrossRef] [PubMed]

171. Kierończyk, B.; Sypniewski, J.; Rawski, M.; Czekała, W.; Swiatkiewicz, S.; Józefiak, D. From Waste to Sustainable Feed Material: The Effect of Hermetia illucens Oil on the Growth Performance, Nutrient Digestibility, and Gastrointestinal Tract Morphometry of Broiler Chickens. Ann. Anim. Sci. 2020, 20, 157-177. [CrossRef]

172. Mbhele, F.G.T.; Mnisi, C.M.; Mlambo, V. A nutritional evaluation of insect meal as a sustainable protein source for jumbo quails: Physiological and meat quality responses. Sustainability 2019, 11, 6592. [CrossRef]

173. Mwaniki, Z.; Neijat, M.; Kiarie, E. Egg production and quality responses of adding up to $7.5 \%$ defatted black soldier fly larvae meal in a corn-soybean meal diet fed to Shaver White Leghorns from wk 19 to 27 of age. Poult. Sci. 2018, 97, 2829-2835. [CrossRef]

174. Mwaniki, Z. Complete Replacement of Soybean Meal with Defatted Black Soldier Fly Larva Meal (BSFLM) in Laying Hen Feeding Programs: Impact on Egg Production and Quality. Ph.D. Thesis, University of Guelph, Guelph, ON, Canada, 2019.

175. Nery, J.; Gasco, L.; Dabbou, S.; Schiavone, A. Protein composition and digestibility of black soldier fly larvae in broiler chickens revisited according to the recent nitrogen-protein conversion ratio. J. Insects Food Feed 2018, 4, 171-177. [CrossRef]

176. Onsongo, V.O.; Osuga, I.M.; Gachuiri, C.K.; Wachira, A.M.; Miano, D.M.; Tanga, C.M.; Ekesi, S.; Nakimbugwe, D.; Fiaboe, K.K.M. Insects for Income Generation Through Animal Feed: Effect of Dietary Replacement of Soybean and Fish Meal With Black Soldier Fly Meal on Broiler Growth and Economic Performance. J. Econ. Entomol. 2018, 111, 1966-1973. [CrossRef]

177. Pieterse, E.; Erasmus, S.W.; Uushona, T.; Hoffman, L.C. Black soldier fly (Hermetia illucens) pre-pupae meal as a dietary protein source for broiler production ensures a tasty chicken with standard meat quality for every pot. J. Sci. Food Agric. 2019, 99, 893-903. [CrossRef] [PubMed]

178. Schiavone, A.; Cullere, M.; De Marco, M.; Meneguz, M.; Biasato, I.; Bergagna, S.; Dezzutto, D.; Gai, F.; Dabbou, S.; Gasco, L.; et al. Partial or total replacement of soybean oil by black soldier fly larvae (Hermetia illucens L.) fat in broiler diets: Effect on growth performances, feed-choice, blood traits, carcass characteristics and meat quality. Ital. J. Anim. Sci. 2017, 16, 93-100. [CrossRef]

179. Schiavone, A.; Dabbou, S.; De Marco, M.; Cullere, M.; Biasato, I.; Biasibetti, E.; Capucchio, M.T.; Bergagna, S.; Dezzutto, D.; Meneguz, M.; et al. Black soldier fly larva fat inclusion in finisher broiler chicken diet as an alternative fat source. Animal 2018, 12, 2032-2039. [CrossRef] [PubMed]

180. Schiavone, A.; Dabbou, S.; Petracci, M.; Zampiga, M.; Sirri, F.; Biasato, I.; Gai, F.; Gasco, L. Black soldier fly defatted meal as a dietary protein source for broiler chickens: Effects on carcass traits, breast meat quality and safety. Animal 2019, 13, $2397-2405$. [CrossRef] [PubMed]

181. Secci, G.; Bovera, F.; Nizza, S.; Baronti, N.; Gasco, L.; Conte, G.; Serra, A.; Bonelli, A.; Parisi, G. Quality of eggs from Lohmann Brown Classic laying hens fed black soldier fly meal as substitute for soya bean. Animal 2018, 12, 2191-2197. [CrossRef]

182. Surendra, K.C.; Tomberlin, J.K.; van Huis, A.; Cammack, J.A.; Heckmann, L.H.L.; Khanal, S.K. Rethinking organic wastes bioconversion: Evaluating the potential of the black soldier fly (Hermetia illucens L.) (Diptera: Stratiomyidae) (BSF). Waste Manag. 2020, 117, 58-80. [CrossRef] [PubMed]

183. Moula, N.; Scippo, M.L.; Douny, C.; Degand, G.; Dawans, E.; Cabaraux, J.F.; Hornick, J.-L.; Medigo, R.C. Leroy, P. Performances of local poultry breed fed black soldier fly larvae reared on horse manure. Anim. Nutr. 2018, 4, 73-78. [CrossRef]

184. Marono, S.; Loponte, R.; Lombardi, P.; Vassalotti, G.; Pero, M.E.; Russo, F.; Gasco, L.; Parisi, G.; Piccolo, G.; Nizza, S.; et al. Productive performance and blood profiles of laying hens fed Hermetia illucens larvae meal as total replacement of soybean meal from 24 to 45 weeks of age. Poult. Sci. 2017, 96, 1783-1790. [CrossRef]

185. Maurer, V.; Holinger, M.; Amsler, Z.; Früh, B.; Wohlfahrt, J.; Stamer, A.; Leiber, F. Replacement of soybean cake by Hermetia illucens meal in diets for layers. J. Insects Food Feed 2016, 2, 83-90. [CrossRef]

186. Kim, Y.B.; Kim, D.H.; Jeong, S.B.; Lee, J.W.; Kim, T.H.; Lee, H.G.; Lee, K.W. Black soldier fly larvae oil as an alternative fat source in broiler nutrition. Poult. Sci. 2020, 99, 3133-3143. [CrossRef]

187. Kozłowski, K.; Ognik, K.; Stępniowska, A.; Juśkiewicz, J.; Zduńczyk, Z.; Kierończyk, B.; Benzertiha, A.; Benzertiha, A.; Józefiak, D. Growth performance, immune status and intestinal fermentative processes of young turkeys fed diet with additive of full fat meals from Tenebrio molitor and Hermetia illucens. Anim. Feed Sci. Technol. 2021, 278, 114994. [CrossRef] 
188. Jankowski, J.; Kozłowski, K.; Zduńczyk, Z.; Stępniowska, A.; Ognik, K.; Kierończyk, B.; Józefiak, D.; Juśkiewicz, J. The effect of dietary full-fat Hermetia illucens larvae meal on gut physiology and growth performance in young turkeys. Anim. Feed Sci. Technol. 2021, 275, 114879. [CrossRef]

189. Giannetto, A.; Oliva, S.; Ceccon Lanes, C.F.; de Araújo Pedron, F.; Savastano, D.; Baviera, C.; Parrino, V.; Lo Paro, G.; Spanò, N.C.; Cappello, T.; et al. Hermetia illucens (Diptera: Stratiomydae) larvae and prepupae: Biomass production, fatty acid profile and expression of key genes involved in lipid metabolism. J. Biotechnol. 2020, 307, 44-54. [CrossRef]

190. Chun, C.Y.; Yoong, L.S.; Kim, L.P.; Hock, T.L.; Ling, L.J. Comparison of Hermetia illucens larvae and pre-pupae as potential aqua feed derived from the biotransformation of organic waste. AIP Conference Proceedings. 2019, 2157, 020008.

191. Liland, N.S.; Biancarosa, I.; Araujo, P.; Biemans, D.; Bruckner, C.G.; Waagbø, R.; Torstensen, B.E.; Lock, E.-J. Modulation of nutrient composition of black soldier fly (Hermetia illucens) larvae by feeding seaweed-enriched media. PLoS ONE 2017, 12, e0183188. [CrossRef]

192. Salomone, R.; Saija, G.; Mondello, G.; Giannetto, A.; Fasulo, S.; Savastano, D. Environmental impact of food waste bioconversion by insects: Application of Life Cycle Assessment to process using Hermetia illucens. J. Clean. Prod. 2017, 140, 890-905. [CrossRef]

193. Wang, S.Y.; Wu, L.; Li, B.; Zhang, D. Reproductive Potential and Nutritional Composition of Hermetia illucens (Diptera: Stratiomyidae) Prepupae Reared on Different Organic Wastes. J. Econ. Entomol. 2020, 113, 527-537. [CrossRef] [PubMed]

194. Gao, Z.; Deng, W.; Zhu, F. Reference gene selection for quantitative gene expression analysis in black soldier fly (Hermetia illucens). PLoS ONE 2019, 14, e0221420. [CrossRef]

195. Zheng, L.; Li, Q.; Zhang, J.; Yu, Z. Double the biodiesel yield: Rearing black soldier fly larvae, Hermetia illucens, on solid residual fraction of restaurant waste after grease extraction for biodiesel production. Renew. Energy 2012, 41, 75-79. [CrossRef]

196. Bondari, K.; Sheppard, D.C. Soldier fly, Hermetia illucens L., larvae as feed for channel catfish, Ictalurus punctatus (Rafinesque), and blue tilapia, Oreochromis aureus (Steindachner). Aquac. Res. 1987, 18, 209-220. [CrossRef]

197. Hu, J.; Wang, G.; Huang, Y.; Sun, Y.; He, F.; Zhao, H.; Li, N. Effects of substitution of fish meal with black soldier fly (Hermetia illucens) larvae meal, in yellow catfish (Pelteobagrus fulvidraco) diets. Israeli J. Aquacul. 2017, 69, 1-9.

198. Fawole, F.J.; Adeoye, A.A.; Tiamiyu, L.O.; Ajala, K.I.; Obadara, S.O.; Ganiyu, I.O. Substituting fishmeal with Hermetia illucens in the diets of African catfish (Clarias gariepinus): Effects on growth, nutrient utilization, haemato-physiological response, and oxidative stress biomarker. Aquaculture 2020, 518, 734849. [CrossRef]

199. Muin, H.; Taufek, N.M.; Kamarudin; Razak, S. A. Growth performance, feed Utilization and body composition of nile tilapia, Oreochromis niloticus (Linnaeus, 1758) fed with different levels of black soldier fly, Hermetia illucens (Linnaeus, 1758) maggot meal diet. Iran. J. Fish. Sci. 2017, 16, 567-577.

200. Devic, E.; Leschen, W.; Murray, F.; Little, D.C. Growth performance, feed utilization and body composition of advanced nursing Nile tilapia (Oreochromis niloticus) fed diets containing Black Soldier Fly (Hermetia illucens) larvae meal. Aquac. Nutr. 2018, 24, 416-423. [CrossRef]

201. Toriz-Roldan, A.; Ruiz-Vega, J.; García-Ulloa, M.; Hernández-Llamas, A.; Fonseca-Madrigal, J.; Rodríguez-González, H. Assessment of Dietary Supplementation Levels of Black Soldier Fly, Hemertia illucens, Pre-Pupae Meal for Juvenile Nile Tilapia, Oreochromis niloticus. Southwest. Entomol. 2019, 44, 251. [CrossRef]

202. Borgogno, M.; Dinnella, C.; Iaconisi, V.; Fusi, R.; Scarpaleggia, C.; Schiavone, A.; Monteleone, E.; Gasco, L.; Parisi, G. Inclusion of Hermetia illucens larvae meal on rainbow trout (Oncorhynchus mykiss) feed: Effect on sensory profile according to static and dynamic evaluations. J. Sci. Food Agric. 2017, 97, 3402-3411. [CrossRef]

203. Cardinaletti, G.; Randazzo, B.; Messina, M.; Zarantoniello, M.; Giorgini, E.; Zimbelli, A.; Bruni, L.; Parisi, G.; Olivotto, I.; Tulli, F. Effects of graded dietary inclusion level of full-fat Hermetia illucens prepupae meal in practical diets for rainbow trout (Oncorhynchus mykiss). Animals 2019, 9, 251. [CrossRef] [PubMed]

204. Rimoldi, S.; Gini, E.; Iannini, F.; Gasco, L.; Terova, G. The effects of dietary insect meal from Hermetia illucens prepupae on autochthonous gut microbiota of rainbow trout (Oncorhynchus mykiss). Animals 2019, 9, 143. [CrossRef] [PubMed]

205. Bruni, L.; Belghit, I.; Lock, E.J.; Secci, G.; Taiti, C.; Parisi, G. Total replacement of dietary fish meal with black soldier fly (Hermetia illucens) larvae does not impair physical, chemical or volatile composition of farmed Atlantic salmon (Salmo salar L.). J. Sci. Food Agric. 2020, 100, 1038-1047. [CrossRef]

206. Mancini, S.; Medina, I.; Iaconisi, V.; Gai, F.; Basto, A.; Parisi, G. Impact of black soldier fly larvae meal on the chemical and nutritional characteristics of rainbow trout fillets. Animal 2018, 12, 1672-1681. [CrossRef] [PubMed]

207. Dumas, A.; Raggi, T.; Barkhouse, J.; Lewis, E.; Weltzien, E. The oil fraction and partially defatted meal of black soldier fly larvae (Hermetia illucens) affect differently growth performance, feed efficiency, nutrient deposition, blood glucose and lipid digestibility of rainbow trout (Oncorhynchus mykiss). Aquaculture 2018, 492, 24-34. [CrossRef]

208. Huyben, D.; Vidaković, A.; Werner Hallgren, S.; Langeland, M. High-throughput sequencing of gut microbiota in rainbow trout (Oncorhynchus mykiss) fed larval and pre-pupae stages of black soldier fly (Hermetia illucens). Aquaculture 2019, 500, 485-491. [CrossRef]

209. Rumpold, B.A.; Speckmann, H.; Schlüter, O.; Kloas, W.; Prochnow, A. Potentials of a biogenic residue-based production of Hermetia illucens as fish meal replacement in aquafeed for Oncorhynchus mykiss in Germany. J. Insects Food Feed 2018, 4, 5-18. [CrossRef]

210. Sealey, W.M.; Gaylord, T.G.; Barrows, F.T.; Tomberlin, J.K.; McGuire, M.A.; Ross, C.; St-Hilaire, S. Sensory Analysis of Rainbow Trout, Oncorhynchus mykiss, Fed Enriched Black Soldier Fly Prepupae, Hermetia illucens. J. World Aquac. Soc. 2011, 42, 34-45. [CrossRef] 
211. Terova, G.; Rimoldi, S.; Ascione, C.; Gini, E.; Ceccotti, C.; Gasco, L. Rainbow trout (Oncorhynchus mykiss) gut microbiota is modulated by insect meal from Hermetia illucens prepupae in the diet. Rev. Fish Biol. Fish. 2019, 29, 465-486. [CrossRef]

212. Magalhães, R.; Sánchez-López, A.; Leal, R.S.; Martínez-Llorens, S.; Oliva-Teles, A.; Peres, H. Black soldier fly (Hermetia illucens) pre-pupae meal as a fish meal replacement in diets for European seabass (Dicentrarchus labrax). Aquaculture 2017, 476, 79-85. [CrossRef]

213. Lock, E.R.; Arsiwalla, T.; Waagbø, R. Insect larvae meal as an alternative source of nutrients in the diet of Atlantic salmon (Salmo salar) postsmolt. Aquac. Nutr. 2016, 22, 1202-1213. [CrossRef]

214. Biancarosa, I.; Sele, V.; Belghit, I.; Ørnsrud, R.; Lock, E.J.; Amlund, H. Replacing fish meal with insect meal in the diet of Atlantic salmon (Salmo salar) does not impact the amount of contaminants in the feed and it lowers accumulation of arsenic in the fillet. Food Addit. Contam.Part A Chem. Anal. Control. Expo. Risk Assess. 2019, 36, 1191-1205. [CrossRef]

215. Stenberg, O.K.; Holen, E.; Piemontese, L.; Liland, N.S.; Lock, E.J.; Espe, M.; Belghit, I. Effect of dietary replacement of fish meal with insect meal on in vitro bacterial and viral induced gene response in Atlantic salmon (Salmo salar) head kidney leukocytes. Fish Shellfish. Immunol. 2019, 91, 223-232. [CrossRef]

216. Zarantoniello, M.; Randazzo, B.; Truzzi, C.; Giorgini, E.; Marcellucci, C.; Vargas-Abúndez, J.A.; Zimbelli, A.; Annibaldi, A.; Parisi, G.; Tulli, F.; et al. A six-months study on Black Soldier Fly (Hermetia illucens) based diets in zebrafish. Sci. Rep. 2019, 9, 1-12. [CrossRef]

217. Caimi, C.; Renna, M.; Lussiana, C.; Bonaldo, A.; Gariglio, M.; Meneguz, M.; Dabbou, S.; Schiavone, A.; Gai, F.; Elia, A.C.; et al First insights on Black Soldier Fly (Hermetia illucens L.) larvae meal dietary administration in Siberian sturgeon (Acipenser baerii Brandt) juveniles. Aquaculture 2020, 515, 734539. [CrossRef]

218. Li, S.; Ji, H.; Zhang, B.; Tian, J.; Zhou, J.; Yu, H. Influence of black soldier fly (Hermetia illucens) larvae oil on growth performance, body composition, tissue fatty acid composition and lipid deposition in juvenile Jian carp (Cyprinus carpio var. Jian). Aquaculture 2016, 465, 43-52. [CrossRef]

219. Zhou, J.S.; Liu, S.S.; Ji, H.; Yu, H.B. Effect of replacing dietary fish meal with black soldier fly larvae meal on growth and fatty acid composition of Jian carp (Cyprinus carpio var. Jian). Aquac. Nutr. 2018, 24, 424-433. [CrossRef]

220. Guerreiro, I.; Castro, C.; Antunes, B.; Coutinho, F.; Rangel, F.; Couto, A.; Serra, C.R.; Peres, H.; Pousão-Ferreira, P.; Matos, E.; et al. Catching black soldier fly for meagre: Growth, whole-body fatty acid profile and metabolic responses. Aquaculture 2020, $516,734613$. [CrossRef]

221. Vongvichith, B.; Morioka, S.; Sugita, T.; Phousavanh, N.; Phetsanghanh, N.; Chanthasone, P.; Pommachan, P.; Nakamura, S. Evaluation of the efficacy of aquaculture feeds for the climbing perch Anabas testudineus: Replacement of fishmeal by black soldier fly Hermetia illucens prepupae. Fish. Sci. 2020, 86, 145-151. [CrossRef] 